\title{
Kim jest oblubieniec w przypowieści o dziesięciu pannach (Mt 25,1-13)? Między tradycyjnymi i współczesnymi próbami zrozumienia
}

\author{
Who Is the Bridegroom in the Parable of the Ten Virgins (Matt 25:1-13)? \\ Between Traditional and Modern Interpretations
}

\author{
ARNOLD ZAWADZKI \\ Instytut Nauk Biblijnych, Katolicki Uniwersytet Lubelski Jana Pawła II \\ e-mail: zawadzki.a@icloud.com \\ ORCID: 0000-0002-7827-7881
}

\begin{abstract}
Aвstract: The main aim of the article is to present, employing the tools of historical criticism, six problematic "nodes" around which a complex exegesis of the Parable of the Ten Virgins (Mt 25:1-13) has evolved over the centuries. These six problems are: (a) the identity of $\pi \alpha \rho \theta \varepsilon \dot{v o r}$ (the changes in the meaning stemming from the accommodation process); (b) the aspect of competition within a patriarchal society (good or bad?); (c) the bride (present or absent?); (d) the role of the virgins in the wedding procession (the chance of finding a husband, witnesses to the marriage contract, part of the beauty of the wedding ceremony?); (e) lamps or torches?; and (f) the fate of the foolish virgins (punishment or harm?). Moreover, historical criticism also points out a number of problems concerning the critica textus, as well as the intricate process of editing which influenced the understanding of the parable. Yet the most important question, as encapsulated in the article, is the identity and proper understanding of the bridegroom: does this character (as tradition has it) represent Jesus himself or, conversely, might it perhaps serve here as a personification of social injustice?
\end{abstract}

KeYwords: historical criticism, virgin, bridegroom, Parable of the Ten Virgins, lamps, torches, social injustice

SŁowA KLuCZE: metoda historyczno-krytyczna, dziewica, oblubieniec, przypowieść o dziesięciu pannach, lampy, pochodnie, niesprawiedliwość społeczna

Z rozumienie przypowieści o dziesięciu pannach (Mt 25,1-13) w taki sposób, w jaki pierwsi słuchacze Jezusa mogli ją zrozumieć, wymaga od współczesnego egzegety przeanalizowania kontekstu historyczno-kulturowego, w którym ten obraz powstał i funkcjonował. Trudno bowiem wyobrazić sobie, aby Żydzi słuchający Jezusa widzieli w pannach roztropnych siostry zakonne, a w radosnym obrazie uczty weselnej zatrważającą zapowiedź Sądu Ostatecznego (jak w Mt 25,31-46). A przecież chrześcijańska tradycja zaktualizowała przesłanie tej przy- 
powieści w takim właśnie kluczu ${ }^{1}$ I choć ta interpretacja wpisała się na trwałe w życie Kościoła (historia effectuum) i stała się dla chrześcijan duchową pożywką na przestrzeni wielu stuleci (nie wolno więc jej lekceważyć), wysiłek wierzących w poszukiwaniu woli Bożej, wyrażonej w tym tekście usque ad plenitudinem divinae veritatis, jest nadal potrzebny. Zaniechanie $\mathrm{w}$ tym względzie byłoby niewłaściwe i niezgodne z żywą Tradycją Kościoła ${ }^{2}$. Co więcej, wpisywałoby się w proces „talmudyzacji” Biblii, typowy dla lektury fundamentalistycznej, gdzie jedna interpretacja, raz utrwalona przez tradycję, stawałaby się jedyną wykładnią badanego tekstu i dlatego należałoby na niej poprzestać. Przy takim podejściu tradycyjna interpretacja byłaby ważniejsza niż żywe słowo Boże ${ }^{3}$, którego zrozumienie w Kościele (perceptio) rozwija się i pogłębia (crescit) nie tylko przez kontemplację, ale również przez naukową analizę, szczególnie wtedy, gdy - dzięki zastosowaniu metody historyczno-krytycznej ${ }^{4}$ - pojawiają się nowe bodźce do intelektualnej i duchowej refleksji nad badanym tekstem.

\section{Wstęp teologiczno-metodologiczny}

Kościół, dowartościowując intelektualny trud w dążeniu do głębszego zrozumienia słowa Bożego (perceptio), uwypuklił eklezjalne powołanie biblisty-teologa i przypisał mu ważną i odpowiedzialną rolę. Skoro więc zrozumienie i pogłębienie słowa Bożego postępuje w Kościele (crescit) nie tylko za przyczyną magisterium biskupów, którzy otrzymali niezawodny charyzmat prawdy (charisma veritatis certum), ale również dzięki intelektualnemu dociekaniu wierzących ${ }^{5}$, nie należy odrzucać a priori współczesnych interpretacji, które pomagają wniknąć w sens

1 Np. teksty wspólne o dziewicach w brewiarzu, gdzie święte dziewice idą na spotkanie Pana z zapalonymi lampami, wyraźnie nawiązują do przypowieści z Mt 25,1-13.

2 Dei verbum 8: „Ecclesia scilicet, volventibus saeculis, ad plenitudinem divinae veritatis iugiter tendit, donec in ipsa consummentur verba Dei”. Kościół nie może więc ustać w ciągłym dążeniu do pełni prawdy Bożej przez pogłębianie słowa Bożego.

3 Taka zachowawcza postawa charakteryzuje egzegezę żydowską, dla której Talmud i tradycja rabiniczna (np. interpretacje Rasziego) są ważniejsze od Tory.

4 Dei verbum 12. Metoda historyczno-krytyczna w dzisiejszym rozumieniu zawiera w sobie dwa momenty, wzajemnie się uzupełniające: moment diachroniczny (geneza i redakcja tekstu) i synchroniczny (interpretacja tekstu kanonicznego). W początkowej fazie rozwoju (tzw. faza bultmannowska) metoda historyczno-krytyczna była tożsama z metodą diachroniczną (stąd jej alternatywna nazwa - metoda morfogenetyczna) i koncertowała uwagę głównie na wyodrębnianiu gatunków literackich oraz poszukiwaniu ich historii.

5 F. Testaferri, La parola viva (Assisi: Cittadella Editrice 2009) 119: „...il binomio studiocontemplazione [nella Dei verbum 8 - przypis mój]... ha il pregio di rinnovare da una parte la consapevolezza della vocazione ecclesiale del teologo che si inserisce nel dinamismo ecclesiale della comprensione della tradizione, mentre dall'altra serve a mostrare come non spetti solo al magistero contribuire alla cosiddetta crescita verso la verità tutta intera, pur con i dovuti distinguo...". 
tekstu natchnionego lepiej ${ }^{6}$ niż robiła to niegdyś tradycyjna egzegeza. Środki, jakie dziś mamy do dyspozycji, pozwalają pełniej przekazać wiernym prawdę o zbawieniu. Jednak w tym ciągłym dążeniu do zrozumienia Pisma Świętego Kościół podkreśla, że zarówno magisterium biskupów, jak i naukowe dociekanie pełnią rolę służebną, podporządkowaną słowu Bożemu ${ }^{7}$, którego skuteczności nie może zastąpić nawet najważniejszy dokument Kościoła czy najbardziej poruszający traktat teologiczny - ,słowo Boże jest bowiem żywe, skuteczne i ostrzejsze niż wszelki miecz obosieczny, przenikające aż do rozdzielenia duszy i ducha, stawów i szpiku, zdolne osądzić pragnienia i myśli serca" (Hbr 4,12). Świadomy tego Kościól, od najpierwszych lat swego istnienia nie przestaje pochylać się nad słowem Bożym, szukając „mądrości wiodącej ku zbawieniu przez wiarę w Chrystusie Jezusie" (2 Tm 3,15). Nie bez powodu więc przed pięćdziesięcioma laty Kościół włączył do swojego instrumentarium egzegetycznego metodę historyczno-krytyczną, która znajduje szerokie i owocne zastosowanie w egzegezie katolickiej i przyczynia się do odnowy biblijno-liturgicznej chrześcijańskiego życia.

Metoda historyczno-krytyczna, stosowna rzetelnie (z naukowym rygorem) i właściwie, czyli w obrębie żywej Tradycji Kościoła, do której należy nie tylko Pismo Święte (locutio Dei scripto consignata), ale i cały przekaz wiary o Bożym objawieniu (verbum Dei Ecclesiae concreditum et integre transmissum) ${ }^{8}$, została dowartościowana przez Sobór Watykański II na tyle, że jej syntetyczny opis znalazł się w Konstytucji dogmatycznej Dei verbum 12 (4 i 5 akapit). Rekomendując tę metodę jako narzędzie pozwalające najlepiej ${ }^{9}$ zbliżyć się do zamiaru autora natchnionego, bo w nim - zgodnie z dogmatycznym nauczeniem Kościoła - ukryty jest zamiar autora Boskiego ${ }^{10}$, Kościół dystansuje się od innych metod, niosących w sobie ryzyko instrumentalizacji tekstu natchnionego na poparcie własnych, subiektywnych domniemywań. Owszem nie zostały one całkowicie odrzucone, ale ich wykorzystanie w egzegezie katolickiej jest uprawnione o tyle, o ile uprzednio przeanalizowano tekst zgodnie z zasadami metody historyczno-krytycznej,

6 Lepiej, czyli z większym poszanowaniem tekstu i kontekstu literacko-eklezjalnego badanego fragmentu.

7 Dei verbum 10: „Magisterium non supra verbum Dei est, sed eidem ministrat...”.

8 Kościół bowiem czerpie pewność dotyczącą swej wiary nie przez samo Pismo Święte.

9 Zob. przypis 6.

10 Dei verbum 11-12: ,... id, quid auctores inspirati... asserunt, retineri debeat assertum a Spiritu Sancto... interpres Sacrae Scripturae, ut perspiciat, quid Ipse [Deus — przypis mój] nobiscum communicare voluerit, attente investigare debet, quid hagiographi reapse significare intenderint et eorum verbis manifestare Deo placuerit". Sobór odszedł od terminologii scholastycznej, rozróżniającej między autorem boskim - przyczyną nadrzędną (causa principalis) - a autorami natchnionymi - przyczynami narzędziowymi (causae instrumentales). Choć pojawiała się ona jeszcze w schemacie przygotowawczym De fontibus z 1961 roku, opracowanym przez Sebastiaana Trompa SJ, ostatecznie została odrzucona na rzecz uwypuklenia pełnej współpracy Boga z człowiekiem w procesie natchnienia. Dlatego zamysł autora natchnionego jest nośnikiem zamysłu samego Boga. 
otwierając sobie pole do dalszego badania na podstawie metod alternatywnych. Można powiedzieć, że stosowanie innych metod ma charakter wtórny i jest skutkiem zastosowania metody historyczno-krytycznej ${ }^{11}$. Chodzi bowiem o stosowanie w pierwszej kolejności metody obiektywizującej, trzymającej się jak najściślej badanego tekstu i pozwalającej uniknąć kakofonii sprzecznych interpretacji, których jedynym arbitrem słuszności nie jest tekst, lecz subiektywne/konfesyjne przekonanie tego czy innego egzegety. Nietrudno dostrzec, że wskazanie jednej, obiektywizującej metody ma również wymiar ekumeniczny i apologetyczny, bo pozwala spojrzeć na tekst natchniony przez pryzmat tego, co, jak i dlaczego autor biblijny chciał rzeczywiście powiedzieć. I choć nie jest możliwe, by egzegeta stosujący metodę historyczno-krytyczną znalazł odpowiedź na wszystkie nurtujące go pytania, bo tekst często na to nie pozwala (ale dostrzeżenie takiej bariery dzięki metodzie historyczno-krytycznej też świadczy o jej obiektywizującej wartości), to jednak jego wysiłek powinien iść w kierunku jak najwierniejszego odtworzenia zamysłu autora i późniejszych redaktorów, który został utrwalony w tekście kanonicznym. W przeciwnym razie interpretacja Biblii przywodziłaby na myśl Księgi Sybillińskie lub inne pogańskie wyrocznie, które interpretowano na dwa, często wykluczające się sposoby ${ }^{12}$, a samego autora natchnionego sprowadzałaby do roli pasywnego medium, które nieświadome zamysłu Boga, bezwiednie wypełniałoby Jego polecenia.

Niniejszy artykuł ilustruje, jak metoda historyczno-krytyczna wchodzi w dialog z tradycyjną interpretacją Mt 25,1-13, niekiedy korygując jej nieścisłości, niekiedy ją ubogacając, i do jakich wniosków prowadzi, jeśli spojrzymy na ten sam tekst raz z perspektywy Jezusa i jego adresatów, innym razem z perspektywy wspólnoty Mateuszowej, która kilkadziesiąt lat później poddała go refleksji teologicznej i akomodowała ${ }^{13}$ do zmienionej sytuacji. W ten sposób metoda historyczno-krytyczna przyczynia się do rozwoju teologii i ubogaca żywą Tradycję Kościoła.

$11 \mathrm{Na}$ przykład jeśli na podstawie metody historyczno-krytycznej stwierdzi się, że autor analizowanego tekstu wykorzystywał zasady starożytnej retoryki, pozwala to na powtórne przebadanie tekstu na podstawie metody retorycznej.

12 Na przykład słynna wyrocznia Ibis redibis non morieris in bello w zależności od interpunkcji mogła być pozytywna (Ibis, redibis, non morieris in bello) bądź negatywna (Ibis, redibis non, morieris in bello).

13 Akomodacja to dostosowanie przekazu i formy nauki Jezusa do mentalności i kultury odbiorcy bądź do nowych warunków życia Kościoła bez naruszania jej istoty. Dokonuje się przez objaśnienia słów, umiejscowienia ich w nowym kontekście lub uwypuklenia/doprecyzowania (dodanie lub pominięcie) odpowiednich terminów. Przykładem akomodacji może być inkulturacja, thumaczenie $\mathrm{z}$ aramejskiego na grecki itp. Akomodacja aktualizuje więc nauczanie Jezusa, aby przetrwało niezmienione w swej istocie i jednocześnie było dostępne dla ludzi wszystkich czasów. W ten sposób słowa Jezusa zachowują swą świeżość i żywotność w każdej sytuacji. Akomodacja jest de facto interpretacją, która przedstawia pierwotny sens tekstu jako znaczący i aktualny dla dzisiejszego człowieka (W. Egger, Metodologia del Nuovo Testamento [Bologna: Edizioni Dehoniane 1996] 224). Istnieje też potoczne rozumienie akomodacji, polegające na ustanawianiu analogii czysto werbalnych między samymi słowami, które 


\section{Elementy problematyczne w tekście greckim Mt 25,1-13 (cruces exegetum)}

Zanim przystąpi się do egzegezy, należy wyodrębnić te elementy, które w tekście greckim rzutują na zrozumienie przypowieści i przybliżają podłoże historyczno-teologiczne, na którym rozwinął się proces jej redakcji/akomodacji we wspólnocie Mateuszowej. Wtedy łatwiej dostrzec pewne dialektyczne napięcie między pierwotną recepcją słów Jezusa w środowisku palestyńskim i recepcją tych słów w środowisku diaspory żydowskiej, prawdopodobnie w Antiochii Syryjskiej, gdzie - jak się przyjmuje ${ }^{14}$ - powstała Ewangelia św. Mateusza. Pozwoli to ukazać, że kerygmat Jezusa, przechodząc z jednego środowiska do drugiego, zyskiwał na wielowymiarowości i głębi, nabierał nieco innego kolorytu, ale jego integralność pozostawała nienaruszona.

Od samego początku, jeszcze na etapie tworzenia się kanonu Nowego Testamentu, interpretacja jednej wypowiedzi Jezusa opierała się na hermeneutycznej unifikacji wielu Jego słów i czynów, aby wyrazić w miarę całościowo jedną chrystologię i stać się wyznaniem wiary autora/redaktora, w której wspólnota Kościoła rozpoznawała (czy powinna rozpoznać) swoją własną wiarę. Ten moment hermeneutyczny, scalający wiele wypowiedzi Jezusa w jedną chrystologię, odpowiada postulatowi metody historyczno-krytycznej, by na etapie analizy synchronicznej odnieść omawianą przypowieść nie tylko do kontekstu literackiego - bliższego (= mowa eschatologiczna Mt 23,1-26,1) i szerszego (= Ewangelia św. Mateusza), ale również do całej Tradycji Kościoła.

Jednak uprzednio należy przeprowadzić analizę diachroniczną na tyle, na ile tekst na to pozwala. Prowadzi ona do atomizacji badanego tekstu (textus), by dostrzec jego wewnętrzną strukturę, zobaczyć newralgiczne punkty-węzły,

w różnych epokach - pomimo identycznego brzmienia - są nośnikami odmiennych sensów. W konsekwencji taka „akomodacja” fałszowałby sens zamierzony przez autora i wypaczałaby istotę jego przesłania. Pius XII w encyklice Divino afflante Spiritu przestrzegał: , ,. . accomodationibus illis, privato arbitrio inductis et ex rebus longe alienis expetitis, quae quidem divini sermonis non usus sed abusus sunt, studiose diligenterque vitatis...” (,,...starannie i sumiennie wystrzegać się tych akomodacji, które pochodzą z własnej fantazji i są wyprowadzane ze skojarzeń bardzo dalekich, stanowiąc nie korzystanie, lecz nadużywanie słów Bożych..."- tłumaczenie moje); zob. A. Filippi - E. Lora (red.), Enchiridion biblicum (Bologna: Edizioni Dehoniane ${ }^{2} 1994$ ) 592, § 566; zob. też: J. Szlaga, „Hermeneutyka biblijna ”, Wstęp ogólny do Pisma Świętego (red. J. Szlaga) (Poznań - Warszawa: Pallotinum 1986) 193-195 (zwłaszcza 194, 3 akapit od dołu); R. Aguirre Monasterio - A. Rodríguez Carmona, Vangeli Sinottici e Atti degli Apostoli (ISB 6; Brescia: Paideia 1995) 31-32; natomiast ks. J. Czerski („Interpretacja tekstów biblijnych w liturgii”, STV 49/1 (2011) 153-154) myli metodę midraszową, stosowaną w przepowiadaniu i w liturgii pierwotnego Kościoła, z akomodacją w sensie potocznym.

14 Hipoteza o antiocheńskim pochodzeniu Ewangelii św. Mateusza została sformułowana po raz pierwszy przez anglikańskiego badacza B.H. Streeter, The Four Gospels. A Study of Origins (London: Macmillian and Company 1924) 500-527. 
które w splocie rozmaitych wątków pokazują, gdzie jest osnowa, gdzie wpleciona nitka pełni funkcję dekoracyjną, a gdzie praktyczną. W ten sposób metoda historyczno-krytyczna uczy powściągliwości, by nie przypisywać tekstowi tego, czego nie mówi i nie szukać w nim rzeczy nieistniejących. W przeciwnym razie, nie potrafiąc wznieść spojrzenia ku rzeczom istotnym, egzegeza przypominałaby poszukiwanie motyli pod Łukiem Tytusa i przekraczałaby cienką linię, jaka istnieje między wzniosłością i śmiesznością.

Analiza diachroniczna uwypukla pięć problemów, kluczowych przy interpretacji przypowieści Mt 25,1-13: tożsamość bohaterek, a w szczególności ich rola i podział na mądre i głupie (2.1); Sitz im Leben, czyli środowisko, w którym obraz powstał i był odbierany (2.2); znaczenie ả $\mu \eta ́ v$ w Mt 25,12 (2.3); możliwość rekonstrukcji pierwotnej wersji Jezusowej przypowieści i odpowiedź na pytanie, kim był autor? (3). Po naświetleniu wymienionych kwestii zostanie przedstawiona interpretacja przypowieści na podstawie tradycyjnej (przedsoborowej) egzegezy (4) i egzegezy historyczno-krytycznej (5).

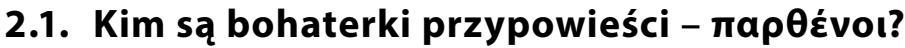

Ewangelijna przypowieść opisuje dziesięć młodych kobiet za pomocą greckiego słowa $\pi \alpha \rho \theta \varepsilon ́ v o 1$, które zwyczajowo thumaczy się jako „dziewice”, ,panny” (sing. $\dot{\eta} \pi \alpha \rho \theta \dot{\varepsilon} v o s,-o v, f$.). Używając tego terminu, za którym kryje się hebrajski

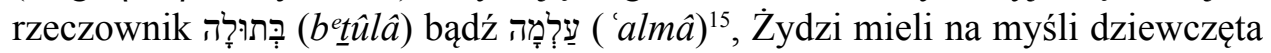
trzynasto-, albo co najwyżej czternastoletnie ${ }^{16}$, które zgodnie z ich kodem kultu-

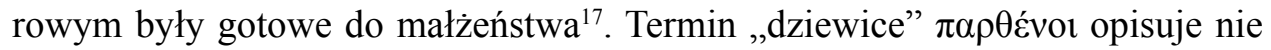
tyle wiek, fizjologię czy detale anatomiczne tych dziewcząt, co ich status społeczny w społeczeństwie patriarchalnym ${ }^{18}$. W takim społeczeństwie dziewczęta

15 L. Koehler - W. Baumgartner - J.J. Stamm, Wielki stownik hebrajsko-polski i aramejskopolski Starego Testamentu (Warszawa: Vocatio 2008) I, 157-158 i 779-780. Wehnam uważa,

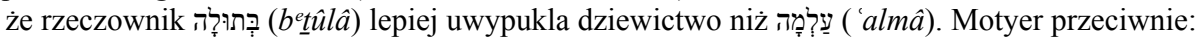

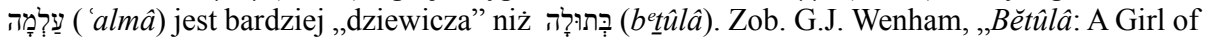
Marriageable Age", VT 22 (1972) 325-348; J.A. Motyer, Prophecy of Isaiah. An Introduction and Commentary (Downers Grove, IL: InterVarsity 1993) 84.

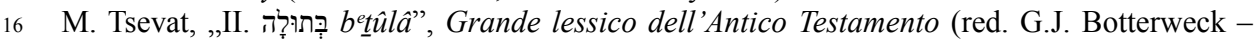
H. Ringgren) (Brescia: Paideia 1988) I, 1783: „,..è da supporre una parola comune a tutte le lingue semitiche, batūl $(t)$, col significato «(ragazza) giovane in età pubere e immediatamente posteriore»".

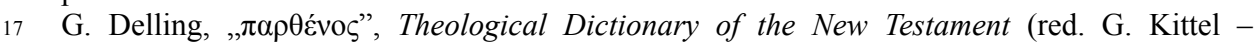
G. Friedrich) (Grand Rapids 1995) V, 826-837 (zwłaszcza 831-837): ,a young woman ready for marriage"; zob. też C. Spicq, Theological Lexicon of the New Testament (Peabody, MA: Hendrickson 1994) III, 45-49.

18 Ch.L. Quarles, Matthew. Exegetical Guide to the Greek New Testament (Nashville, TN: B\&H Publishing Group 2017) 296: „П $\propto \rho \theta \varepsilon \dot{v o s}$, -ov, $\dot{\eta}$ refers to a young woman who has not had sexual relations and is old enough to marry. In the context of wedding rituals, the term is comparable to 
- młode kobiety ( $\pi \alpha \rho \theta \varepsilon ́ v o \imath)$ - są „,wystawione na rynek matrymonialny” jako kandydatki do zamążpójścia. Zasady składania i przyjmowania ofert ustalają ojcowie lub potencjalni kandydaci na mężów. Głównym zadaniem tych kobiet ( $\pi \alpha \rho \theta \varepsilon ́ v o r)$ jest zaprezentować się z jak najlepszej strony jako przyszłe małżonki, dobre, zaradne, przewidujące, przedsiębiorcze, wrażliwe i czujne (zob. poemat o dzielnej niewieście z Prz 31,10-31). Potwierdza to również starożytna pozabiblijna literatura żydowska i typowo biblijno-mądrościowy podział dziewcząt na mądre ( $\varphi \rho o v i ́ n o \imath)$ i głupie ( $\mu \omega \rho \alpha i ́)$.

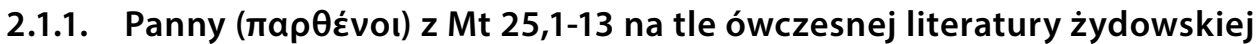

Jeśli porównamy obraz nakreślony przez Jezusa w Mt 25,1-13 z sytuacją młodych kobiet opisywanych przez literaturę żydowską pozabiblijną, dostrzeżemy analogie. Na przykład Miszna przytacza słowa rabbana Szymona ben Gamaliela, który mówił tak: „w Izraelu nie ma szczęśliwszych dni od 15. dnia miesiąca Ab i od dnia przebłagania (Jom Kippur). W tych bowiem dniach córki jerozolimskie wychodzą w białych szatach, i robią to ukradkiem, żeby nie zawstydzić tych, którzy ich nie posiadali - bo wszystkie szaty potrzebowały oczyszczającego zanurzenia. Córki jerozolimskie wychodzą więc i pośród winnic wykonują taniec. I co wtedy mówią? «Młodzieńcze, podnieś wzrok i uważaj na to, co wybierasz. Zwróć swe oczy nie na urodę. Zwróć swe oczy na rodzinę. Kłamliwy jest wdzięk i marne jest piękno; chwalić należy niewiastę, co boi się Pana. A mówi się także: Uznajcie owoce jej rak, niech w bramie stawia jej czyny»" (mTaan 4,8 - thumaczenie moje $)^{19}$. Słowa córek jerozolimskich, przytoczone w Misznie, nawiązują do zakończenia poematu o dzielnej niewieście (Prz 31,30-31) i wskazują, że młody mężczyzna powinien poszukiwać w kobiecie takich cech i wybrać taką żonę, która zapewni mu szczęśliwe życie rodzinne.

Innym przykładem jest Talmud babiloński, który komentując ten sam fragment Miszny i zawartą w niej tradycję tanaicką, przytacza słowa dziewcząt szukających męża w nieco innej wersji: „[Czytamy w Misznie:] $]^{20}$ Córki izraelskie wychodzą i tańczą pośród winnic. [Potem] Miszna dodaje: «kto nie miał żony, szedł tam»-Szlachetnie urodzone, które były pośród nich mówiły: «Młodzień-

"bridesmaid" (NLT) if one maintains the historic distinction between bridesmaids and matrons".

19 Dziewiąty traktat Ta'anit (hebr. umartwienie), znajdujący się w drugim porządku Moed w Misznie, zawiera przepisy dotyczące postów, ich motywacji i celów oraz sposobów poszczenia i odprawiania modłóww dni postne; mTaan 4,8:

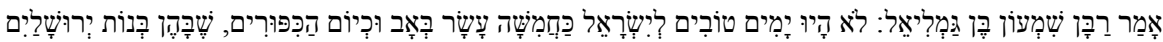

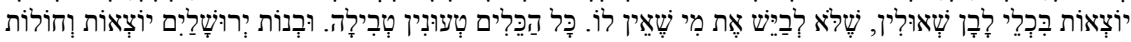

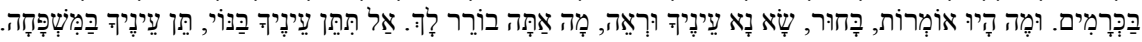

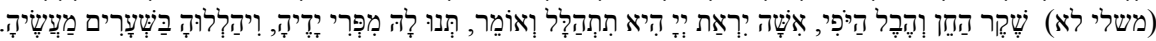

W nawiasach kwadratowych dodatki moje. 
cze etc... (וכו)». Rabbani-tanaici wyjaśniają [powyższy cytat z Miszny]: Piękne, które były wśród nich, co mówiły? «Zwróćcie swe oczy na naszą urodę, bo nie chodzi o (samą) kobietę, lecz o jej piękno». Szlachetnie urodzone, które były pośród nich, co mówiły? «Zwróćcie swe oczy na rodzinę, bo nie chodzi o [samą] kobietę, lecz o [spłodzenie] dzieci». Brzydkie, które były pośród nich, co mówi-

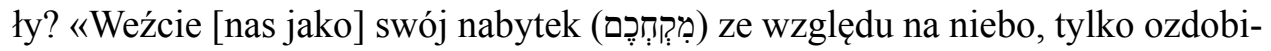

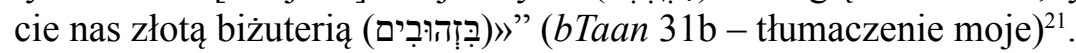

Można zauważyć, że w przypowieści Jezusa (Mt 25,1-1) - w odróżnieniu od dwóch zacytowanych tekstów rabinicznych - okazją dla młodych kobiet, aby zaprezentować się z jak najlepszej strony, nie jest taneczne święto pośród winnic,

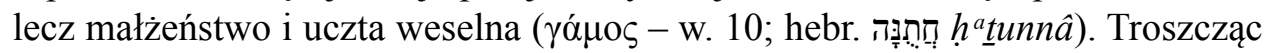
się o swoje lampy, wykazują się zapobiegliwością i przezornością, i w ten sposób zwracają na siebie uwagę młodzieńców przybywających z oblubieńcem.

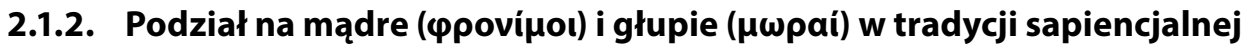

Przypowieść Jezusa z Mt 25,1-13 wpisuje się nie tylko w żydowską tradycję międzytestamentową i pobiblijną, ale również w tradycję biblijną, w szczególności tę mądrościową. Przykładem może być Pieśń nad Pieśniami, gdzie zaślubiny

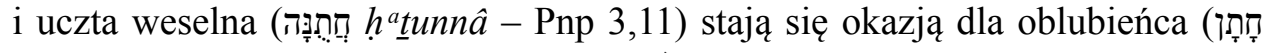
hạt tāan - Iz 61,10; Ps 19,6) i oblubienicy ( כַ kallâ - Iz 61,10) do wyrażenia wzajemnej miłości. Ale ich miłosny flirt i erotyzująca zabawa stwarzają sposobność dla obecnych tam dziewcząt z Jerozolimy - córek syjońskich - aby wziąć w niej udział i przyciągnąć uwagę młodzieńców (Pnp 5,8; zob. też 1,5; 2,7; 3,5.10.11; $5,16 ; 8,4)$. Z kontekstu wynika bowiem, że na uczcie weselnej są obecni przyja-

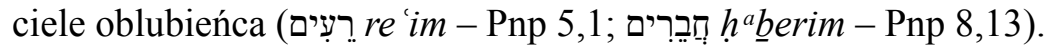

W końcowych wersetach Jezusowej przypowieści można z kolei usłyszeć dalekie echo słów z Księgi Przysłów: „Ręka leniwa sprowadza ubóstwo, ręka zaś pilnych wzbogaca. Człowiek to mądry, co w lecie gromadzi” (Prz 10,4-5a). Motyw lampy też może być reminiscencją poematu o dzielnej niewieście z Księgi Przysłów, gdzie mędrzec przypomina, iż mądra i przedsiębiorcza kobieta, dba-

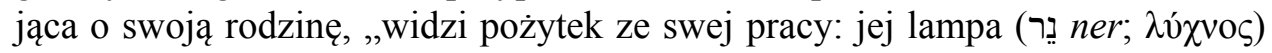
wśród nocy nie gaśnie" (Prz 31,18). Podobny wydźwięk mają słowa Syracha, 
które przypominają, jak ważne dla przyszłości młodej kobiety jest jej inteligencja i zaradność: „Córka roztropna ( $\left.\varphi \rho v^{\prime} \mid \mu \eta\right)$ pozyska sobie męża, a córka, która wstyd przynosi, zgryzotą dla swego ojca" (Syr 22,4).

Innym sapiencjalnym akcentem przypowieści, wywodzącym się ze Starego Testamentu jest przeciwstawienie kobiet mądrych ( $\left.\varphi \rho \operatorname{covi}_{\mu} \mathrm{o}\right)$ kobietom głupim ( $\mu \omega \rho \alpha i ́)$ i ich współzawodnictwo. Kobiety mądre przewyższają głupie swoją przezornością i pilnością. Głupie zaś są nierozważne i nieprzygotowane na moment próby. To przeciwstawienie nie jest tylko pedagogicznym zabiegiem uwypuklającym kontrast między mądrością i głupotą, wskazującym pozytywny wzór do naśladowania, ale również wezwaniem, by w poszukiwaniu osobistego szczęścia umieć podejmować wyzwanie i rywalizację. Przykładem może być dyptyk z Prz 9: kobieta-mądrość buduje dom i wystawia ucztę (Prz 9,1-6) versus kobieta-głupota, która siedząc leniwie przy bramie miasta, kusi niedoświadczonych młodzieńców i sprowadza ich na bezdroża (Prz 9,13-18).

W przypowieści Jezusa już na samym początku (Mt 25,2) widzimy dwie przeciwstawione sobie grupy dziewcząt. Dialog między nimi wyraźnie wskazuje, że współzawodniczą między sobą. Współzawodnictwo było też cechą charakterystyczną obrazu nakreślonego przez Talmud (zob. wyżej § 2.1.1.): ładne dziewczyny chciały przyciągnąć spojrzenia swoją urodą, z kolei dziewczyny pochodzące $z$ dobrych domów przyciągały uwagę swym pochodzeniem i troską o szczęście rodzinne.

Tego typu podejście w literaturze sapiencjalnej nie powinno dziwić. W społeczeństwach patriarchalnych przeciwstawienie kobiety dobrej kobiecie złej miało charakter pedagogiczny i było sposobem wychowania seksualnego, ale niekiedy mogło prowadzić do niesprawiedliwego uciemiężenia kobiet, które na to nie zasłużyły. Hermeneutyka feministyczna w swej neo-ortodoksyjnej formie zwraca na to uwagę (zob. tzw. kryterium socjologiczne) ${ }^{22}$. Dlatego z perspektywy

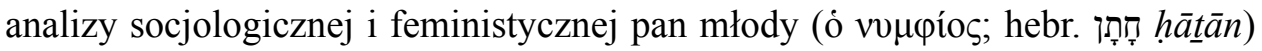
w przypowieści Jezusa jest rzecznikiem osądu społecznego, jaki dokonuje się nad kobietami mniej zaradnymi. Mówiąc „nie znam was” (Mt 25,12) rozstrzyga konkurs i dla tych kobiet drzwi się zatrzaskują. Przegrały.

\subsubsection{Słowo nap日źvoc w późniejszej tradycji Kościoła}

Przesłanie skierowane do Żydów oddziaływało na nich za pomocą ich kodu kulturowego, wywoływało określone skojarzenia i skłaniało do ocen wartościują-

22 Papieska Komisja Biblijna, Interpretacja Pisma Świętego w Kościele (Poznań: Pallotinum 1994) 55-57. Zob. też V. Balabinski, „Opening the Closed Door: A Feminist Rereading of «Wise and Foolish Virgins» (Mt 25,1-13)”, The Lost Coin. Parables of Women, Work and Wisdom (red. M.A. Beavis) (London - New York: Sheffield Academic Press 2002) 71-97. 
cych zgodnie z ich systemem aksjologicznym. Kiedy jednak to samo przesłanie zostało zaimplementowane w świecie hellenistycznym i rzymskim, zaczęto je odnosić do innej matrycy pojęciowej. Dokonywało się to na rozmaite sposoby $^{23}$, ale w przypadku słowa $\pi \alpha \rho \theta \varepsilon ́ v o \varsigma$ pozbawiono je hebraizującego zabarwienia i zaczęło uwypuklać jego klasyczne znaczenie. Dlatego czytający Biblię po grecku nawróceni poganie widzieli w nim wyłącznie kobietę żyjącą w stanie niezamężnym i poświęcającą się Bogu - kobietę, która dobrowolne wyrzekła się pożycia seksualnego. Słuchacz ewangelii zacznie więc dostrzegać w dziewictwie symbol czystości (zob. np. 2Kor 11,2), która pozwala zwrócić serce człowieka ku rzeczywistości wznioślejszej, pozaziemskiej i nadprzyrodzonej, nadchodzącej z królestwem Bożym w eschatologicznej pełni ${ }^{24}$. Jest to przykład, w jaki sposób Kościół, przenosząc przesłanie ewangelii z jednego kontekstu kulturowego do drugiego, wybierał takie znaczenia dla pojedynczych słów (szczególnie tych wieloznacznych), aby dostosować je do mentalności adresata i lepiej uwypuklić pewien aspekt w postawie i nauczaniu Jezusa, niekoniecznie związany bezpośrednio $\mathrm{z}$ interpretowanym tekstem ${ }^{25}$. Akomodacja językowa i kulturowa stawała się w ten sposób skutecznym środkiem ewangelizacji i przyczyniała się do metodycznego rozpowszechniania chrześcijaństwa wśród pogan.

Klasyczne znaczenie słowa $\pi \alpha \rho \theta \dot{v} v \varsigma^{26}$ zaczęło wpływać na tradycyjną interpretację przypowieści o dziesięciu pannach (Mt 25,1-13) ${ }^{27}$. Katalizatorem tej hermeneutyki było chrześcijańskie dowartościowanie dziewictwa w osobie i życiu Jezusa i jego naśladowców. Niemałą rolę w procesie akomodacji odegrała kultura rzymska $^{28}$, w której dziewictwo było wartością religijno-społeczną, szanowaną i prawnie chronioną 29 . Westalki - kapłanki Westy (virgines vestales) - były sześcioosobowym

23 Zob. przypis 13.

24 L. Ryken - J.C. Wilhoit - T. Longmann III, „Verginità”, Le immagini bibliche. Simboli, figure retoriche e temi letterari della Bibbia (Milano: Edizioni San Paolo 2006) 1574-1575: „L'idea di purezza..., connessa a quella del guardare oltre, verso qualcosa di più grande che viene incontro e che muove a una maggiore maturità, lo ha reso concetto adatto ad essere riferito a Israele..., che ora guarda alle future benedizioni...".

25 W przypadku przypowieści o dziesięciu pannach nie wydaje się, żeby w jej centrum znajdował się temat dziewictwa.

26 Dobry i nadal aktualny artykuł na ten temat, zob. F. Gryglewicz, „Dziewictwo w greckiej terminologii biblijnej", RTK 22/1 (1975) 25-37.

27 Kongregacja ds. Instytutów Życia Konsekrowanego i Stowarzyszeń Życia Apostolskiego, Ecclesiae Sponsae Imago, 19: „L'appartenenza esclusiva a Cristo, sancita col vincolo nuziale, mentre alimenta in loro [nelle vergini - przypis mój] la vigile attesa del ritorno dello Sposo glorioso (Mt 25,1-13), le associa in modo peculiare al suo sacrificio redentore e le dedica alla edificazione e alla missione della Chiesa nel mondo (Col 1,24)".

28 W kulturze greckiej dziewictwo było przede wszystkim prerogatywą bogin - Ateny Partenos i Artemidy - chociaż nie wyklucza się, że dziewicami były również kobiety, które pełniły służbę w ich świątyniach.

29 Cyceron, In Catilinam oratio tertia, 4, 9; tenże, In Catilinam oratio quarta, 9, 18 (red. C. Stegmann, Die Rede über den Oberbefehl des Cn. Pompeius und die Katilinarischen Reden [Leipzig - Berlin: Teubner 1912] 58); tenże, De legibus, II, 8, 20; tenże, De re publica, II, 14, 26; 
„Zakonem”, na czele którego stała przełożona ${ }^{30}$. Zamieszkiwały „klasztor” (atrium Vestae) i pełniąc służbę bożą, wyróżniały się odpowiednim strojem i zachowaniem. Ich obowiązkiem było czuwanie dniem i nocą przy świętym ogniu w świątyni Westy. Jeśli sprzeniewierzyły się swemu powołaniu i zaniedbały podtrzymywanie świętego ognia lub złamały śluby czystości, podlegały karze chłosty, a nawet śmierci. Dziewictwo, czuwanie i służba boża - te trzy pojęcia u Rzymian były ze sobą nierozerwalnie związane i znajdowały analogię w chrześcijańskiej postawie człowieka, który ofiarowywał siebie - również w swej cielesności - Chrystusowi, jedynemu Panu. Żyjąc radami ewangelicznymi, taki człowiek, wolny od ziemskich trosk, naśladował Mistrza i z dnia na dzień stawał się znakiem królestwa Bożego na ziemi.

Najstarsza chrześcijańska interpretacja przypowieści o dziesięciu pannach, wyrażona również $\mathrm{w}$ ikonografii ${ }^{31}$, wykorzystywała te analogie i pośrednio ukazywała, że słowo Boże nie jest biernym zapisem określonych słów, które trzeba kurczowo strzec i bronić, ale jest przede wszystkim siłą, która skutecznie pokonuje bariery kulturowe, dosięga człowieka w jego życiu i środowisku, i buduje Kościół, wspólnotę ludzi przemienionych łaską Boga. Innymi słowy, w poszukiwaniu języka zrozumiałego dla ówczesnego człowieka proces akomodacji kulturowo-językowej i interpretacja były de facto aktem wiary w moc słowa Bożego, które dosięga wszystkich ludzi stając się dla nich źródłem prawdy, zbawienia i moralności. Ta akomodacja nie byłaby możliwa, gdyby między żywym słowem Boga i człowiekiem nie istniała wspólna płaszczyzna porozumienia, ustanowiona w teandrycznej naturze Chrystusa. Tak jak boska i ludzka natura łączą się w osobie Jezusa, tak przez analogię w procesie akomodacji słowo Boga łączy się ze słowem i kulturą człowieka, aby dialog między nimi mógł być możliwy. Wszystko, co w człowieku jest dobre, bez względu na pochodzenie etniczne czy kulturowe, zostało w Jezusie zaakceptowane i oczyszczone, aby być podstawą dialogu Boga z człowiekiem i wzajemnego zrozumienia. Jeśli rzymskie (pogańskie) cnoty w świetle słowa Bożego mogły zostać uznane za cnoty chrześcijańskie, działo się tak, dlatego że Jezus przez tajemnicę wcielenia nadał człowieczeń-

III, 10, 17 (red. i thum. C.W. Keyes, Cicero on the Republic, on the Laws [Loeb Classical Library 213; Cambridge, MA: Harvard University Press 1928] 248, 387); Horacy, Pieśni, I, 2,27; I, 12, 22; III, 22, 1; III, 30, 9 (red. F. Klinger, Quinti Horatii Flacci Opera [Leipzig: Teubner $\left.{ }^{5} 1970\right]$ 65, 82, 84); Owidiusz, Tristia, II, 311 (red. i thum. A.L. Wheeler - G.P. Goold, Tristia. Ex Ponto [Loeb Classical Library 151; Cambridge, MA: Harvard University Press 1924] 132). Można zadać pytanie, czy instytucja dziewictwa konsekrowanego była znana również w Izraelu. Jedynym tekstem sugerującym istnienie takiej instytucji jest Sdz 11,34-40 (ewentualnie Ps 68,27); zob. J.H. Walton - V.H. Matthews - M.W. Chavalas, Komentarz historyczno-kulturowy do Biblii Hebrajskiej (Warszawa: Vocatio 2005) 285.

30 L. Winniczuk, Ludzie, zwyczaje $i$ obyczaje starożytnej Grecji i Rzymu (Warszawa: PWN $\left.{ }^{4} 2008\right) 416$.

31 Miniatura w Kodeksie $\Sigma$ z Rossano (VI w.) przedstawia panny roztropne ubrane na wzór rzymskich westalek. Podobnie fresk z IV w. w katakumbach św. Wawrzyńca (Cyriaki) w Rzymie przy via Tiburtina. 
stwu z jego strukturą kreaturalną, z jego historią i kulturą wartość pełną i nieprzemijającą, wynosząc je na poziom Boga. Wcielenie Jezusa uzasadnia więc konieczność akomodacji przesłania Ewangelii, aby objawienie było dostępne i zrozumiałe dla każdego człowieka ( $D V 13$ ). Człowieczeństwo Jezusa staje się kanałem objawienia - przestrzenią, w której Bóg mógł nawiązać przyjacielską relację z człowiekiem i objawić mu swą wolę.

Przypowieść o dziesięciu pannach przez pryzmat jednego słowa ( $\pi \alpha \rho \theta \varepsilon ́ v o \varsigma)$ zyskiwała - w tym procesie akomodacji - nowy wymiar, który miał zdominować tradycyjną interpretację już w okresie patrystycznym ${ }^{32}$. Przykładów jest bardzo dużo. Św. Cyryl Aleksandryjski uważał, że olej w lampach to jednocześnie prawo naturalne i Mojżeszowe oraz każdy rodzaj cnoty zasiany przez Boga w ludzkich sercach. I choć wszyscy ludzie zostali jednakowo obdarowani cnotami, to jednak nie wszyscy starają się wcielać je w życie. Dlatego zdadzą sprawę przed Boskim Sędzią, gdy przy powtórnym przyjściu Chrystusa, na głos anielskiej trąby zostaną wybudzeni ze snu śmierci, by pokazać, na ile ich lampy są wypełnione cnotami i uczynkami Prawa. Według św. Cyryla alegoryczny obraz dziesięciu dziewic jest jednak zawężony do przywódców ludu, którzy powinni być czyści na ciele i duszy. Liczba 10 zostaje rozbita na dwie piątki, ponieważ każdy czas ma pięć okresów (niemowlęctwo, dzieciństwo, młodość, dojrzałość i starość), w którym znajdują się jednocześnie mądrzy i głupi. Św. Augustyn też dawał alegoryczne wyjaśnienie przypowieści: dziewicami są wszystkie dusze ochrzczonych (animae christianorum). Świętość dziewictwa nie polega jedynie na powstrzymaniu pięciu zmysłów od grzechu ${ }^{33}$, lecz również na posiadaniu dobrych uczynków

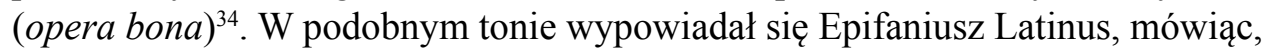
że mądrymi dziewicami jest się nie tylko w ciele, ale również i w duszy - a mądrość dziewictwa widać przede wszystkim w dziełach miłosierdzia ${ }^{35}$. Również św. Jan Chryzostom z interpretacją w kluczu antyascetycznym wpisuje się w tę samą tradycję: asceza i powstrzymanie się od związków seksualnych to za mało, by być uczniem Jezusa. Można być wielkim ascetą, a jednocześnie być jak owe

32 Cyryl Aleksandryjski, „Fragment 280”, Matthäus-Kommentare aus der griechischen Kirche (red. J. Reuss) (Berlin: Akademie-Verlag 1957) 250-251.

33 Augustyn, Kazanie 93,2-3 (PL 38, 574): „Qui ergo se abstinet ab illicito visu, ab illicito tactu, ab illicito odoratu, ab illicito gustu, ab illicito tactu, propter integritatem, virginis nomen accepit". W słowach św. Augustyna pobrzmiewa dalekie echo interpretacji Orygenesa, który widział w pannach symbol ludzkich zmysłów. Owe zmysły dzięki działaniu Syna Bożego, Wcielonego Słowa stały się „dziewicze“, czyli oczyszczone; Orygenes, Commentariorum series in evangelium Matthaei (red. E. Klostermann) (Die Griechischen christlichen Schriftsteller der ersten drei Jahrhunderte 35; Leipzig: J.C. Hinrich 1933) 63.

„Virgines propter abstinentiam ab illicitis sensibus; lampades habent propter opera bona“ - Augustyn, Kazanie 93,2-3 (PL 38, 574). Panny jako dusze są interpretowane w nurcie kalwińskim i purytańskim: T.R. Jones, „Union With Christ: The Existential Nerve Of Puritan Piety", Tyndale Bulletin 41/2 (1990) 199.

35 Epifaniusz Latinus, Interpretatio evangeliorum, 36 (PLSuppl 3, 892). 
głupie panny, które choć ujarzmiły pokusy ciała, nie zdołały pokonać własnej chciwości. Muszą więc udać się do „sprzedających oliwę”, czyli do ubogich i potrzebujących, aby świadczyć im uczynki miłosierdzia ${ }^{36}$. I chociaż św. Jan Chryzostom należy do tzw. szkoły antiocheńskiej, stawiającej na dosłowną i typologiczną interpretację Pisma Świętego, owa alegoryczna lektura - inspirowana metodą Filona - była rozwijana głównie w szkole aleksandryjskiej, od czasów Klemensa Aleksandryjskiego ${ }^{37}$ i Orygenesa ${ }^{38}$.

Przypowieść rozumiana jako wezwanie do naśladowania świętych dziewic, idących na spotkanie Jezusa - niebieskiego Oblubieńca, usunęła jednak w cień te elementy, które w przesłaniu Jezusa miały charakter judaizujący i odpowiadały żydowskiej mentalności pierwszych adresatów (zob. wyżej $\S \S 3.1 .1$ i 3.1.2). Metoda historyczno-krytyczna stara się więc odzyskać i dowartościować ten zapomniany sens przypowieści.

\subsubsection{Dziewictwo Maryi}

Kościół oddalając się (czasowo i przestrzennie) od kultury żydowskiej, otworzył się na wpływ kultury grecko-rzymskiej i zaczął dokonywać refleksji nad całościowym nauczaniem Jezusa, wprowadzając do języka teologicznego słowa

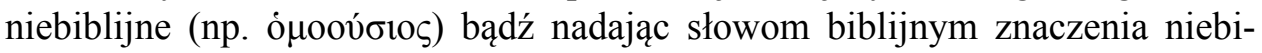

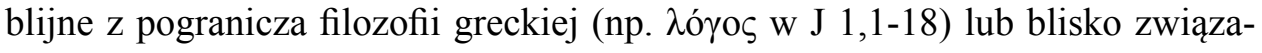
ne z pojęciami religii pogańskiej. Słowo $\pi \alpha \rho \theta \varepsilon ́ v o \varsigma$ - wydaje się - uległo takiej kulturowej akomodacji, która doprowadziła do paradoksalnej zamiany znaczeń: zamiast opisywać kobietę, która chce założyć rodzinę i urodzić dzieci, stało się terminem technicznym wskazującym na kobietę składającą śluby dziewictwa, by poświęcić się Bogu na drodze trzech rad ewangelicznych, czystości, ubóstwa i posłuszeństwa. Największy wpływ na ugruntowanie takiego znaczenia w tradycji Kościoła miało dziewictwo Matki Bożej.

Należy jednak podkreślić, że słowo $\pi \alpha \rho \theta \dot{v} v o \varsigma$ użyte w Nowym Testamencie również w odniesieniu do Maryi opisywało ją jako młodą kobietę, przeznaczoną do małżeństwa, która jeszcze nie obcowała cieleśnie z mężczyzną (Mt 1,23; Łk 1,27: „dziewica poślubiona mężowi”). Dziewictwo Maryi było zwyczajowym wymogiem i warunkiem wstępnym kontraktu małżeńskiego, i nie miało charakteru świadomie religijnego ${ }^{39}$. Nie było znakiem konsekracji. Jednak z per-

\footnotetext{
36 Jan Chryzostom, Commentarius in Mattheum. Homilia 58 (PG 58, 712-713).

37 Klemens Aleksandryjski, Stromata 7,12 (Alexandrian Christianity [red. H. Chadwick J.E. Oulton J. E.] [Library of Christian Classics; Philadelphia: Westminster 1954] 139).

$38 \quad$ Zob. przypis 33.

39 W przeciwnym razie dziewicza konsekracja Maryi uniemożliwiłaby zaślubiny z Józefem. Delling, , , $\alpha \rho \theta \varepsilon \dot{\varepsilon} v o \varsigma^{“}, 834$ : „Mary's virginity ... is obviously not asserted by the NT for ascetic
} 
spektywy kolejnych, ewangelijnych wydarzeń było namacalnym (anatomicznym wręcz) potwierdzeniem, że Jezus jest Synem Bożym, bo począł się za sprawą Ducha Świętego (Mt 1,18.20; Łk 1,35), bez współudziału mężczyzny. Dlatego obrona dziewictwa Maryi (nawet jeśli nie było to dziewictwo konsekrowane) jest obroną boskiej natury Jezusa ${ }^{40}$. Bóg wykorzystując żydowski obyczaj, aby do zaślubin szła młoda dziewica, zachował nienaruszone łono Maryi, aby przez nie, w sposób nadprzyrodzony i przez działanie wykraczające poza naturalny porządek, objawić swego Syna. Niejednokrotnie w ekonomii objawienia, trzy porządki - porządek kultury, porządek historii i porządek natury stawały narzędziami nadprzyrodzonego działania Boga.

W związku z tym, biblijną podstawą konsekracji Maryi jest raczej Fiat a nie słowo $\pi \alpha \rho \theta \varepsilon ́ v o \varsigma$, które podkreślało jedynie jej młody wiek, dziewiczą nienaruszoność i status społeczny. Decyzja Maryi, aby bezwarunkowo wypełnić Boże polecenie (Łk 1,38: „Oto ja służebnica Pańska”) przemilczawszy swe zobowiązanie względem Józefa, była rzeczywistym wyrazem ufności i całkowitego oddania się Bogu, w czym Tradycja Kościoła słusznie zacznie dostrzegać pierwowzór chrześcijańskiej konsekracji. Biblijne spojrzenie na konsekrację - nie przez pryzmat słowa $\pi \alpha \rho \theta \dot{v} v o \varsigma$ - daje więc głębsze zrozumienie, że człowiek ofiarowując się Bogu, oddaje całego siebie, a nie jedynie jedną sferę życia - swoją seksualność. Maryja oddała Bogu wszystko, aby otrzymać od Niego wszystko. Temu powołaniu pozostała wierna zawsze, również w misji, jaką otrzymała od konającego Jezusa. Fiat Maryi (Łk 1,38) jest więc dla niej ,pierwotną decyzją" - „decyzją źródłową” (niem. Ur-Entscheidung), zawierającą w sobie wszystkie pozostałe decyzje, jakie będzie podejmować później. Nie tylko ona, ale i nowy lud Boży, jakim jest Kościół, którego ona jest Matką i żywym obrazem. W Maryjnej Ur-Entscheidung dostrzegamy też wzór dla naszych dzisiejszych decyzji i postanowień podejmowanych w wierze. Innymi słowy, życie Maryi, od tej decydującej chwili, będzie nieustannym wychodzeniem poza samą siebie; będzie zostawianiem za sobą samej siebie, swoje plany na przyszłość, swój sposób postrzegania rzeczywistości, własne przekonania jako coś, co stoi na przeszkodzie w realizacji Bożego dzieła zbawienia. I dopiero w takim pełnym sensie może być

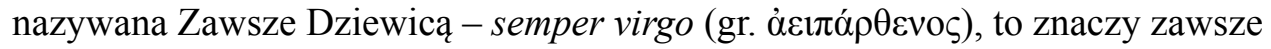
otwartą na Boga i Jego miłość do człowieka.

Trywializowanie decyzji Maryi, sprowadzając ją do roli „surogatki”, która „wypożycza” Bogu swe łono na czas określony, by urodzić Jezusa, a zaraz potem wraca do poprzedniego życia, jakby nic się nie stało, spotkało się z ostrą reakcją Kościoła od samego początku - nawet wtedy, gdy podpierano się tekstem bi-

reasons. That Mary continued to live as a virgin even after the birth of Jesus is a view which the Western Church adopted only after 350 . The concept of the virgin birth of Jesus is not meant to disparage the marriage bond".

Dogmat o dziewictwie Maryi jest podporządkowany dogmatowi chrystologicznemu. 
blijnym z Mt 1,25 („,...lecz [Józef] nie zbliżał się do Niej, aż porodziła Syna”). Owszem ten tekst jest problematyczny, ale i on potwierdza, że istota oddania się Bogu w obrębie życia małżeńskiego ${ }^{41}$ nie tkwi w seksualnej ascezie. Poza tym perspektywa Józefa nie musiała być początkowo taka sama, jak perspektywa Maryi. Widzimy bowiem, że Józef też musi pokonać drogę wiary i stopniowo otwierać się na działanie łaski, która została dana Maryi. I choć na podstawie samej Biblii nie sposób udokumentować jednoznacznie faktu wiecznego dziewictwa Maryi, nauczanie Kościoła jest jasne. Papież Leon Wielki pisząc do Flawiana, arcybiskupa Konstantynopola, 13 czerwca 449 roku (Lectis dilectionis tuae) potwierdza niewzruszoność wiary i powołania Maryi jako Matki Jezusa, czego znakiem jest jej dziewictwo przed i po porodzie: „,[Jezus] został poczęty z Ducha Świętego w łonie Dziewicy Matki, która tak Go wydała na świat bez naruszenia swego dziewictwa, jak Go w nienaruszonym dziewictwie niegdyś poczęła..." ${ }^{42}$. Bardziej zdecydowanie wypowiada się papież Marcin I na Soborze Laterańskim I (5-31 październik 649 roku) przeciwko monoteletystom: „Jeśli ktoś nie wierzy rzeczywiście i prawdziwie w zgodzie ze świętymi ojcami, że Bożą Rodzicielką jest święta, zawsze dziewica, nieskalana Maryja, bo w sposób rzeczywisty i prawdziwy w ostatnich czasach poczęła bez nasienia, z Ducha Świętego i bez zepsucia urodziła tego, który jest zrodzony z Boga Ojca przed wszystkimi wiekami, Boga Słowo, i że jej dziewictwo nadal pozostało nienaruszone również po porodzie, niech będzie potępiony"43. Nienaruszalność dziewictwa Maryi jest nienaruszalnością jej wiary i powołania, i nie można jej sprowadzać do fizjologicznego detalu w duchu średniowiecznych dyskusji, które stosując sylogizm pseudoteologiczny (poród Jezusa nie mógł być naturalny, bo Jego poczęcie też nie było naturalne) niosły ze sobą ryzyko zanegowania ludzkiej natury Jezusa. Maryja pozostanie na zawsze „naczyniem Ducha Świętego” bez względu na to, czy działanie Boga dokonuje się w niej w porządku natury, czy też go przekracza.

41 Na podstawie NT można wywnioskować, że Maryja zdecydowała się na małżeństwo. Również początkowa decyzja Józefa, aby oddalić od siebie brzemienną Maryję, wskazuje na jego pierwotny zamiar założenia rodziny. Nie można więc mówić, że ich zaślubiny były jedynie eskamotażem dziewiczej konsekracji. Oboje chcieli być rodziną w pełnym tego słowa znaczeniu.

42 ,[Iesus] Conceptus quippe est de Spiritu Sancto intra uterum virginis matris, quae illum ita salva virginitate edidit, quemadmodum salva virginitate concepit...".

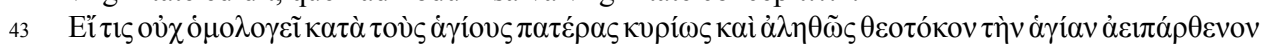

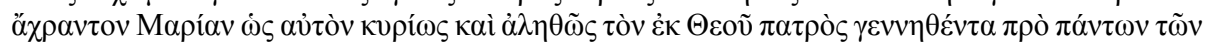

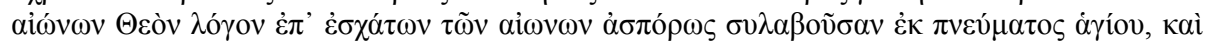

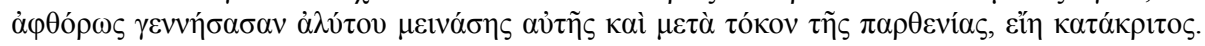
$\mathrm{Si}$ quis secundum sanctos Patres non confitetur proprie et secundum veritatem Dei genitricem sanctam semperque virginem et immaculatam Mariam, utpote ipsum Deum Verbum specialiter et veraciter, qui a Deo Patre ante omnia saecula natus est, in ultimis saeculorum absque semine concepisse ex Spiritu Sancto, et incorruptibiliter eam genuisse, indissolubili permanente et post partum eiusdem virginitate, condemnatus est. 
Kościół powiązał dziewictwo Maryi z apokryficznym opowiadaniem o jej ofiarowaniu w świątyni ${ }^{44}$, w której wychowywała się jako mała dziewczynka. Niewielka odległość oddzielająca świątynię jerozolimską od kościoła św. Anny, gdzie miał wznosić się dom rodziców Maryi i gdzie ona miała się urodzić, uwiarygodnia tradycję, że rzeczywiście wychowywała się w bliskości świątyni, czego ślad przetrwał w kalendarzu liturgicznym 21 listopada (Praesentatio Virginis Mariae). Jednak istotą liturgicznego wspomnienia jest uwypuklenie działania Bożej łaski, która przygotowała Maryję na moment, kiedy świadomie - przez Fiat - otworzyła się na Boży plan, by stać się narzędziem w jego realizacji. Ewangelie kanoniczne, nie wspominając o ślubach dziewictwa Maryi poprzedzających zaślubiny z Józefem, potwierdzają taką lekturę: wszystko, kim Maryja była, zawdzięczała jedynie uprzedzającej łasce Boga (zob. part. perf. med. $\kappa \varepsilon \chi \alpha \rho ı \omega \mu \varepsilon ́ v \eta$ - Łk 1,28), a nie ludzkiej inicjatywie. Poczęcie Jezusa z Ducha Świętego ma miejsce już po zaślubinach (Mt 1,23; Łk 1,27-28), a sam Józef jest zaskoczony zaistniałą sytuacją - gotów zerwać zaślubiny, gdy odkrył, że Maryja w ludzkim mniemaniu nie jest dziewicą. Nic też nie wskazuje na to, by wiedział o wcześniejszej dziewiczej konsekracji Maryi. Ludzkie plany Maryi i Józefa schodzą na plan dalszy, by zrobić miejsce Bogu, który gwałtownie i w sposób nieoczekiwany wkracza w ich życie ze swoją łaską, a oni tę łaskę przyjmują. Owszem, każde na swój sposób i w swojej kolejności: najpierw Maryja, a potem Józef. Ale to Boża inicjatywa jest przesłanką biblijnych narracji.

W tym świetle tradycja apokryficzna o dziewiczej konsekracji Maryi w dzieciństwie, wpisuje się więc $\mathrm{w}$ ten sam proces akomodacji, któremu podlegało

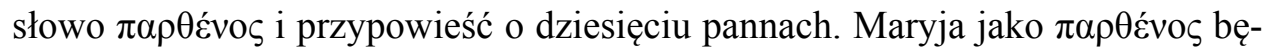
dzie przedstawiana jako poślubiona Bogu - Jego Oblubienica. Nie dziwi więc, że wątek maryjny pojawia się również $\mathrm{w}$ interpretacji przypowieści o dziesięciu pannach (Mt 25,1-13). Widać to najlepiej w sztuce chrześcijańskiej. Portale gotyckich katedr przedstawiają dziesięć ewangelicznych panien jako służki bądź druhny Maryi (zob. katedry w Chartres, Longpont, Saint-Thibault, Trewirze i Bambergu $)^{45}$. Sama Maryja u boku Chrystusa wydaje się być Jego Oblubienicą. Mądre panny symbolizują Kościół bądź wierzących, którzy naśladują Maryję w jej oddaniu Chrystusowi i dlatego ich wiara ma charakter oblubieńczy - całkowity. Niekiedy przybierają postać cnót, stając się zachętą do wytrwania w dobrych uczynkach. Z kolei panny nieroztropne są uosobieniem grzechu, głupoty i ślepego zadufania w sobie. Ta swoista Biblia pauperum przekazuje jasne przesłanie: naśladujcie Maryję Dziewicę. Sama asceza/dziewictwo nie wystarcza, bo

44 „Protoewangelia Jakuba” 6-8, Apokryfy Nowego Testamentu. Ewangelie Apokryficzne (red. M. Starowieyski) (Kraków: Wam 2003) I, 272-274.

45 U. Luz, A Commentary on Matthew 21-28 (Hermeneia 61C; Minneapolis, MN: Fortress Press 2005) 237. 
najważniejsza w życiu człowieka wierzącego jest łaska Boga, która pozwala wytrwać przy Chrystusie idąc drogą świętości.

\subsubsection{Konkluzja}

Przypowieść o dziesięciu pannach (Mt 25,1-13) przedstawia dziewczęta ( $\pi \alpha \rho \theta \varepsilon ́ v o u)$, które w kulturze żydowskiej były na tyle dojrzałe, by wejść w dorosłe życie, zawrzeć związek małżeński i założyć rodzinę. Rozmaite publiczne uroczystości stwarzały im dogodną okazję do zaprezentowania się z jak najlepszej strony jako dobre kandydatki na żony i matki, przedsiębiorcze, zaradne i przewidujące. Jednak tradycja Kościoła pod wpływem kultury rzymskiej oraz rozwijającej się chrystologii i mariologii, już w czasach starożytnych zaczęła używać słowa $\pi \alpha \rho \theta \varepsilon ́ v o \zeta$ w znaczeniu religijnym, czyli dosłownie - jako obraz dziewiczej konsekracji w służbie Bogu i Kościołowi, bądź metaforycznie - jako obraz duszy człowieka, połączonej z Bogiem miłością oblubieńczą w wodach chrztu świętego. Dlatego postawa bohaterek przypowieści zaczyna być interpretowana w kluczu dziewictwa konsekrowanego lub chrzcielnego powołania, znajdującego swój pierwowzór w osobie Matki Bożej i w jej oblubieńcznym zawierzeniu Chrystusowi. Mądrość i głupota ewangelijnych dziewic staje się więc przestrogą przed niebezpieczeństwem, że dziewictwo/umartwienie/uświęcenie - choć samo w sobie jest wartością - może być przeżywane na dwa wykluczające się sposoby: dobry lub zły; zbliżający do Chrystusa - Oblubieńca lub od Niego oddalający. Właściwą drogą, prowadzącą ku Oblubieńcowi, jest posiadanie oliwy. Ale by odpowiedzieć na pytanie, czym jest oliwa, potrzebna jest interpretacja metaforyczna, którą rozwiną Ojcowie Kościoła.

Akomodacja kulturowa przesłania ewangelicznego jest czymś stałym w tradycji Kościoła i jest wyrazem wiary w to, że słowo Boże jest żywe i zawsze aktualne. Widzimy jednak, że w czasie, kiedy Jezus opowiedział swą przypo-

wieść, Jego słuchacze - Żydzi - używali innych kategorii myślowych i inaczej rozumieli słowo $\pi \alpha \rho \theta \varepsilon ́ v o \zeta$. Egzegeza historyczno-krytyczna stawia sobie za cel dotarcie, w miarę możliwości, na podstawie dostępnych źródeł do pierwotnego rozumienia słów Jezusa, aby odkryć nową siłę ewangelicznego przesłania, nie odrzucając tradycji Kościoła. Egzegeta katolicki jest więc jak ów ojciec rodziny, który ze swego skarbca wydobywa rzeczy nowe i stare (zob. Mt 13,52).

\subsection{Sitz im Leben - społeczeństwo patriarchalne}

Jednym z ważnych momentów metody historyczno-krytycznej jest ustalenie środowiska pierwotnych adresatów badanego tekstu (tzw. Sitz im Leben), dzięki 
czemu niektóre opisane zachowania - niezrozumiałe dla nas - znajdują wyjaśnienie i pozwalają spojrzeć na przesłanie w nieco innym świetle. Jeśli chodzi o przypowieść o dziesięciu pannach, owym Sitz im Leben jest społeczeństwo patriarchalne ze swoimi regułami współzawodnictwa, zwyczajami organizowania zaślubin, orszaku weselnego i szczególną rolą oblubieńca.

\subsubsection{Współzawodnictwo przeradzające się w bezwzględność}

Ww. 1-2 sugerują, że Jezus opowiada przypowieść z perspektywy człowieka wychowanego w społeczeństwie patriarchalnym, który rozróżnia między dobrą i złą kandydatką na żonę, i wydaje swój osąd. Ponieważ perspektywa patriarchalna nadaje ton całej przypowieści, postawa kobiet roztropnych, które nie chcą użyczyć oliwy koleżankom (ww. 8-9), nie jest poddana bezpośrednio krytyce. Przecież muszą wykazać się przezornością i zabłysnąć w oczach nadchodzących młodzieńców. W słowach Jezusa można jednak dostrzec pewną zawoalowaną krytykę: gdzie solidarność z towarzyszkami? Dzieląc się oliwą, wszystkie miałby równe szanse. Nie trzeba przywoływać przykazania miłości bliźniego, by zauważyć, że zgodnie z kanonami biblijnej etyki, kobiety roztropne zachowały się egoistycznie i poddały się ludzkim regułom współzawodnictwa $^{46}$. Ale skoro społeczeństwo patriarchalne oczekiwało od nich takiego zachowania, one to robią. Ich odmowa była więc społecznie wyczekiwana i nie była niczym zaskakującym. To, co zaskakuje to scena końcowa, która za pomocą hiperboli ukazuje, że w kontekście zaślubin i ogólnego wesela dzieje się coś nieakceptowalnego po ludzku. Jeśli bowiem jedyną przyszłością dla młodej kobiety - tak jak rozumiano ją w społeczeństwie patriarchalnym - było znalezienie sobie dobrego męża, ta przyszłość przed pięcioma dziewczętami zostaje definitywnie zamknięta. Zakończenie przypowieści przedstawia więc osobliwą sytuację: zwyczajowe współzawodnictwo pośród powszechnej radości przeradza się w niezrozumiałą bezduszność, która eliminuje z życia społecznego małej żydowskiej wioski osoby mniej zaradne. Jeśli odłożymy na bok interpretację alegoryczną, warto zadać pytanie, w jakim celu Jezus chciał wzbudzić w słuchaczach przykre wrażenie i w zaskakujący sposób przekształcił humorystyczną opowieść o gapiostwie paru dziewczyn w żenującą (a może zawstydzającą)

46 Ich odpowiedź w w. 9 jest dobitna. W Nowym Testamencie połączenie dwóch przeczeń $\mu \eta ́ \pi o \tau \varepsilon$

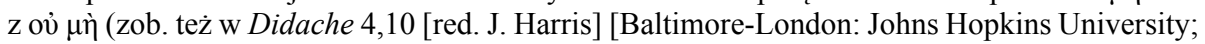
C.J. Clay \& Son 1883]) jest jedyne w swoim rodzaju i nie pozostawia złudzeń, że panny roztropne na pewno nie podzielą się oliwą ze swymi towarzyszkami. Jednak na ich odpowiedź można spojrzeć pozytywnie: one myślą o oblubieńcu, a nie o sobie. Zob. też J. Nolland, The Gospel of Matthew. A Commentary on the Greek Text (NIGTC; Grand Rapids, MI: Eerdmans 2005) 1008; L. Schottroff, Le parabole di Gesù (Brescia: Queriniana 2007) 47. 
historię? Czy sytuacja pięciu dziewcząt, wykluczonych z uczty weselnej, nie miała skłonić słuchaczy do zastanowienia i zadania określonych pytań (zob. podobny zamysł Jezusa w Łk 7,41-43; 10,36-37)? A może od razu mieli doszukiwać się podwójnego dna i pod warstwą literalną przypowieści zobaczyć jej alegoryczne znaczenie? Jeśli tak, to czy mieli do dyspozycji klucz, który pozwoliłby odcyfrować zamysł Jezusa?

\subsubsection{Obecność/nieobecność panny młodej}

Brak wzmianki o pannie młodej dodatkowo wskazuje na patriarchalny charakter środowiska, w którym przypowieść powstała. Z tym argumentem można jednak polemizować, ponieważ krytyka tekstu przytacza szereg dowodów na to, że panna młoda była obecna w w. $1^{47}$, co w tradycji średniowiecznej mogło wzmacniać interpretację maryjną, gdzie u boku Jezusa - Oblubieńca jest Maryja - Oblubienica (zob. wyżej § 2.1.4.). Ale nawet jeśli się je uzna, kolejne wersety (ww. 5.6.11.12) uwypuklają przybycie tylko pana młodego i jego reakcję na spóźnienie pięciu dziewcząt. Tak czy inaczej panna młoda w przypowieści nie ma większego znaczenia. Uwaga słuchacza skupiona jest na osobie oblubieńca, jego zachowaniu i słowach, które determinują postawę i przyszły los dziewcząt. On jest postacią centralną.

\subsubsection{Rola dziewcząt w orszaku weselnym}

Ewentualna obecność panny młodej w w. 1 pozwoliłaby potwierdzić rozpowszechniony w świecie starożytnym zwyczaj, że pan młody po zaślubinach przyprowadza pannę młodą do swego domu ${ }^{48}$. Jeśli dziesięć dziewcząt oczekuje przybycia

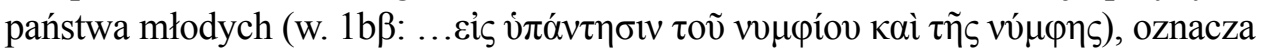
to, że czekają tuż przy domu pana młodego, czyli na ostatnim odcinku drogi prowadzącej z domu oblubienicy do domu oblubieńca. Przypowieść byłaby migawką momentu poprzedzającego wejście młodej pary w intymność małżeńskiej komna-

47 Niektóre manuskrypty (uncjały: kodeks Bezy D z V w., kodeks gruziński z Tibilisi $\Theta \mathrm{z}$ IX w.,

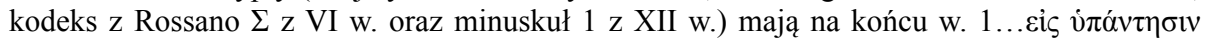

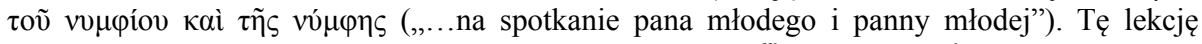
potwierdzają stare łacińskie thumaczenia (np. it ${ }^{\mathrm{a}} \mathrm{z}$ IV w., $\mathrm{it}^{\mathrm{ff} \mathrm{z}} \mathrm{z} \mathrm{V}$ w. lub it $\mathrm{it}^{\mathrm{h}} \mathrm{z}$ W.), Wulgata, tłumaczenia syryjskie, koptyjskie i armeńskie i wielu Ojców Kościoła (np. św. Jan Chryzostom, św. Augustyn). Zob. też B.M. Metzger, A Textual Commentary on the Greek New Testament (Stuttgart - New York: Deutsche Bibelgesellschaft/United Bible Societies 1998) 52-53.

48 J. Jeremias, „vv́ $\mu \varphi \eta ”$, Theological Dictionary of the New Testament (red. G. Kittel) (Grand Rapids, MI: Eerdamans 1967) IV, 1100. 
ty ${ }^{49}$, w której - niewykluczone - dziewczęta miały uczestniczyć bądź pozostawać w jej bezpośredniej bliskości. Pełniłyby więc rolę świadków (עֵ ‘ 'edim) potwierdzających wejście pana młodego i panny młodej w radość nocy poślubnej.

Jeśli jednak dziewczęta oczekują jedynie pana młodego (w. $1 \mathrm{~b} \beta: \ldots$...

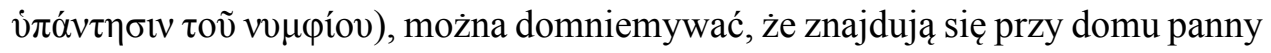
młodej, czyli na początku gościńca wiodącego w kierunku domu oblubieńca. Wezmą udział w zaślubinach, weselu i weselnym orszaku. Ich wyczekująca obecność byłaby więc nieodzownym elementem uświetnienia całej ceremonii, od początku do końca.

O jaki orszak ( $\pi \alpha \rho \alpha \pi \circ \mu \pi \eta ́)$ mogłoby chodzić w przypowieści? Ten prowadzący z domu oblubienicy do domu oblubieńca? Czy raczej krótki orszak wprowadzający państwa młodych $\mathrm{w}$ intymność nocy poślubnej w domu oblubieńca? ${ }^{50}$ Ponieważ nie można odtworzyć zwyczaju zaślubin, jaki obowiązywał w Galilei w I w. po Chr., i związanego z nim orszaku weselnego ${ }^{51}$, egzegeci dokonują jedynie przybliżonej rekonstrukcji obrazu w oparciu o 1 Mch 9,37.39 $9^{52}$ oraz Misznę potwierdzającą (mKetub. 2,1) ( $^{53}$, że panna młoda po zaślubinach była przenoszo-

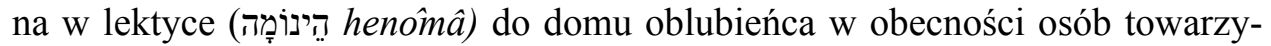

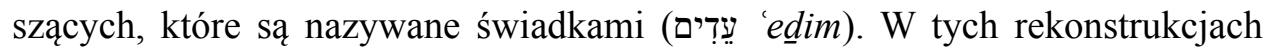
nawiązuje się również do kultury greckiej ${ }^{54}$ i rzymskiej ${ }^{55}$, ukazując przy tym drobne różnice. $\mathrm{W}$ obu kulturach zaślubiny zaczynają się ucztą weselną, której towarzyszą muzyka i tańca (u Greków) lub składanie życzeń i przekazywanie darów (u Rzymian). W międzyczasie ma miejsce rytuał zaślubin polegający na zdjęciu welonu z głowy panny młodej przez jej ojca (u Greków) lub przekazanie oblubienicy oblubieńcowi przez zamężną kobietę (u Rzymian). Następnie rozpoczyna się radosny orszak, który pośród muzyki, śpiewów i pląsów prowadzi oblubienicę do domu oblubieńca. Zarówno u Greków, jak i u Rzymian ma to miejsce w nocy, dlatego pochodnie są niezbędne. Po przejściu przez próg komnaty małżeńskiej, u jej drzwi czuwa przyjaciel oblubieńca, podczas gdy pozostali goście na zewnątrz śpiewają pieśni weselne (u Greków) lub rozchodzą się po-

49 Tak uważa R. Zimmermann („Das Hochzeitsritual im Jungfrauengleichnis. Sozialgeschichtliche Hintergründe zu Mt 25,1-13", NTS 48 (2002) 48-70 (zwłaszcza 69-70).

50 H. Granqvist, Marriage Conditions in a Palestinian Village (Helsinki: Societas Scientiarum Fennica 1935) II, 79-115; J. Jeremias, Le parabole di Gesù (Brescia: Paideia ${ }^{2} 1973$ ) 212-213.

51 M. Mayordomo, „Le ragazze sagge arrivano ovunque...”, Compendio delle parabole di Gesù (red. R. Zimmermann) (Brescia: Queriniana 2011) 776.

52 Zob. też J. Flawiusz, Antiquitates Judaicae, XIII, 20 (red. B. Niese) (Berlin: Weidman 1892).

$53 \quad m K e t u b .2,1$ potwierdzałaby, że zwyczaj orszaku weselnego przetrwał przynajmniej do II w. po Chr., choć tekst Miszny nie mówi jednoznacznie o procesji do domu pana młodego.

54 J.H. Oakley - R.H. Sinos, The Wedding in Ancient Athens (Madison, WI: University of Wisconsin Press 1994) 22-37.

55 S. Treggiari, Roman Marriage. Iusti Coniuges from the Time of Cicero to the Time of Ulpian (Oxford: Clarendon Paperbacks 1991) 161-170. 
zostawiając państwa młodych w ciemności komnaty (u Rzymian) ${ }^{56}$. Na podstawie tych rekonstrukcji wydaje się, że przypowieść nawiązuje do wyczekiwania panien przy domu oblubienicy, kiedy cała ceremonia zaślubin wraz z weselem i długim orszakiem miała jeszcze się zacząć. To dawało im możliwość zaistnienia w towarzystwie podczas wesela, a końcowy orszak stwarzał okazję do lepszego zaprezentowania własnej figury i zwinności ruchów, co dla takich dziewcząt było niezwykle ważne.

Wiedza o orszaku weselnym niewiele wnosi do zrozumienia przypowieści. Dokumentuje jedynie istnienie takiego pochodu i niewykluczone, że obecność dziewcząt nie tylko go uświetniała, ale - jak informuje Miszna - miała również wartość świadectwa, które potwierdzało, że wszystko odbyło się zgodnie z uświęconym zwyczajem, a panna młoda trafiła po zaślubinach do komnaty pana młodego. Jeśli rolą dziesięciu panien było dawanie świadectwa, ostra reakcja pana młodego na spóźnienie się pięciu z nich znajduje proste wytłumaczenie: nie chodziło o to, że zapomniały oliwy, ale że - idąc ją kupić - nie były obecne w kluczowym momencie zaślubin. Ich obecność w dalszej części uroczystości stawała się dla pana młodego bezużyteczna, a nawet ryzykowna, bo w przyszłości, wezwane do złożenia świadectwa, mogłyby wprowadzić zamieszanie swymi zeznaniami i unieważnić prawdziwe świadectwo współtowarzyszek. Skoncentrowane jedynie na sobie i na lampach, myśląc jedynie jak przyciągnąć wzrok młodzieńców, chciały za wszelką cenę uniknąć kompromitacji, gdy spostrzegły, że nie mają oliwy. Ale jednocześnie zapomniały o swym powołaniu - o tym, że ich zadaniem było towarzyszenie państwu młodym. $Z$ takiej perspektywy troska o oliwę byłaby znakiem egoizmu. Byłaby ważniejsza od wypełnienia powołania, a ostra reakcja pana młodego miałaby swoje uzasadnienie - inne niż to, o którym mogliśmy pomyśleć wcześniej (zob. wyżej § 2.2.1.). Warto jednak zauważyć, że gdyby Jezus chciał rzeczywiście uwypuklić wagę świadectwa ( $\mu \alpha \rho \tau v \rho i ́ \alpha)$, wyraziłby to w sposób bezpośredni i odwołanie do Miszny byłoby zbędne. Stąd taka interpretacja, choć ciekawa i teoretycznie możliwa, nie znajduje argumentów na swe poparcie w tekście kanonicznym. Argument pozabiblijny w tym wypadku nie wystarcza. Jego użyteczność w metodzie historyczno-krytycznej objawia się jednak w tym, że pozwala nabrać dystansu do opisanej sytuacji i spojrzeć na dziewczęta i celowość ich obecności z dwóch perspektyw: ich samych i oblubieńca.

56 Ks. Paciorek przekazuje niektóre informacje na ten temat, jednak posługując się nimi należy zachować ostrożność. Trzeba bowiem zauważyć, że ks. Paciorek najpierw opisuje zwyczaj grecki opierając się na Oakley - Sinos, The Wedding in Ancient Athens, 22-37, ale cytuje dzieło Treggiari, Roman Marriage, 161-170, które odnosi się do zwyczaju rzymskiego. Z kolei opisując zwyczaj żydowski ks. Paciorek bazuje na komentarzu Luz, A Commentary on Matthew 21-28, 237, ale w przypisie twierdzi, że wskazany przez niego opis jest autorstwa Mayordomo. Inne tego typu nieścisłości wprowadzają wiele zamieszania w wyjaśnienie przypowieści i rodzą podejrzenie o brak rzetelności. Zob. A. Paciorek, Przypowieści Jezusa. Wprowadzenie i objaśnienie (Częstochowa: Edycja Świętego Pawła 2013) 248. 


\subsubsection{Pochodnie czy lampy?}

Problem wyrażony w tytule paragrafu jest nieco wydumany, bo nie wydaje się, by logika przypowieści i jej zrozumienie wymagały od słuchacza uchwycenia różnicy między pochodnią $\lambda \alpha \mu \pi \alpha$ (hebr. נִ lappid ner). Najważniejsze jest przecież to, że pięciu dziewczętom zabrakło oliwy bez względu na to, czy oliwa miała służyć do pochodni czy lampy. Jednak skoro w domowej przestrzeni używa się lamp, w przestrzeni otwartej zaś, krocząc w orszaku - pochodni ${ }^{57}$, dla dociekliwych komentatorów owo rozróżnienie pomaga w odtworzeniu sceny zaślubin i wyjaśnieniu, na czym polegał błąd nieroztropnych panien. Rozróżnienie między pochodnią i lampą staje się jednak sztuczne i dyskusyjne, gdy zakłada się, że na początku przypowieści pochodnie musiały być zgaszone (skoro dopiero później posłużą do oświetlenia orszaku), lampy zaś zapalone i w ciągłej gotowości (skoro miały oświetlić przestrzeń wewnątrz domu zaraz po przybyciu pana młodego $)^{58}$. Zobaczymy pokrótce, $w$ jakim kierunku idą owe dywagacje i na ile ubogacają zrozumienie przypowieści.

\subsubsection{Terminologia}

W LXX i Nowym Testamencie rzeczownik $\lambda \alpha \mu \pi \alpha ́ \delta \varepsilon \varsigma$ oznacza pochodnie (np. Rdz 15,17; Sdz 7,16.20; 15,4.5; 1Mch 6,39; Hi 41,11; Ez 1,13; Dn 10,6; J 18,3; Ap 4,5; 8,10). Użycie pochodni w Mt 25,1-13 (zob. ww. 3-4.7-8) potwierdzałoby hipotezę, że panny czekają przy domu oblubienicy, gotowe, by - gdy przybędzie oblubieniec - rozpalić pochodnie i rozświetlić uroczysty orszak po zakończeniu uczty weselnej, towarzysząc państwu młodym do domu oblubieńca. Tak też są przedstawiane na starożytnych freskach i obrazach ${ }^{59}$. Gdy pięć z nich spostrzegło, że nie ma czym rozpalić pochodnie, miało wystarczająco dużo czasu, by kupić oliwę. Ceremonia zaślubin i wesele trwały na tyle długo, że dawały taką możliwość - panny mogły zaradzić swej niefrasobliwości i przygotować się na orszak. Nie spodziewały się jednak, że oblubieniec je odprawi.

Tłumaczenie „lampy”, jakie pojawia się we współczesnych wydaniach Biblii (np. BT V, KJV, ESV, ASV, CEI), sugeruje coś innego. Panny mają ze sobą wcześniej zapalone lampy w oczekiwaniu na oblubieńca. Kiedy on przybędzie - a to

57 E. Parisinou, „Lighting the World of Women. Lamps and Torches in the Hands of Women in the Late Archaic and Classical Periods", Greece and Rome 47 (2000) 19-43.

58 Choć tekst przypowieści nie mówi, czy pochodnie/lampy są zapalone przed przybyciem oblubieńca, logika przypowieści wskazuje, że są one zapalone. Trudno sobie bowiem wyobrazić, by panny oczekiwały w ciemności. Poza tym jak mogły wyjść na spotkanie pana młodego ze zgaszonymi pochodniami/lampami (zob. Mt 25,1)?

59 Luz, A Commentary on Matthew 21-28, 230. 
miało stać się lada chwila - od razu wejdą do środka oświetlając swymi kagankami drogę do miejsca zaślubin (jeśli czekają przy domu oblubienicy) lub do komnaty małżeńskiej (jeśli czekają przy domu oblubieńca). Rzeczownik $\lambda \alpha \mu \pi \alpha ́ \varsigma$ w znaczeniu ,lampa” pojawiłby się tutaj po raz pierwszy w literaturze greckiej ${ }^{60}$. Normalnie język grecki klasyczny użyłby słowa $\lambda v_{\chi}{ } v \varsigma^{61}$.

\subsubsection{Niuanse interpretacyjne}

Jednak nie zwyczaj językowy czy kontekst kulturowo-społeczny jest tu decydujący, ale tradycyjna interpretacja przypowieści ${ }^{62}$. I to ona skłania większość komentatorów/thumaczy, by wobec dylematu pochodnie czy lampy? - opowiedzieć się za „lampami”. Dlaczego? Lampy są na tyle małymi naczyniami, że oliwa wypaliła się w oczekiwaniu na oblubieńca (jego przybycie o północy w logice przypowieści jest ważne). Jednocześnie okazało się, że pięć panien nie było wystarczająco przezornych, by zabrać z sobą dodatkową ilość oliwy na taką ewentualność. Nie przewidziały takiej sytuacji. W ten sposób ich nieprzygotowanie zostaje uwypuklone i napiętnowane. Również reakcja oblubieńca i końcowe wezwanie stają się zrozumiałe: „czuwajcie więc, bo nie znacie dnia ani godziny" (Mt 25,13). Poza tym informacja, że oblubieniec wraz z pięcioma pannami wszedł do środka (,... i drzwi zamknięto” - Mt 25,10) jest ważna, dlatego że w odróżnieniu od pochodni, lamp używano w zamkniętej przestrzeni.

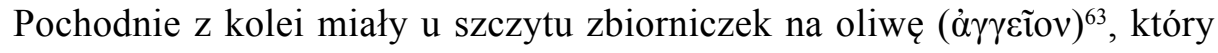
nawilżał obwiązane dokoła włosie $\mathrm{z}$ wełny lub z lnu i pozwalał na długie podtrzymywanie ognia w otwartej przestrzeni. W przestrzeni zamkniętej istniało ryzyko wzniecenia pożaru bądź zadymienia, gdy płonące włókno spadało na ziemię $^{64}$. Zakłada się (na co wskazywałby sam tekst przypowieści), że pochodnie nie były zapalone przed przybyciem oblubieńca. Jeśli więc panny, mimo wielu prób, nie są w stanie rozpalić pochodni (,nasze pochodnie gasną" ${ }^{65}-\mathrm{Mt}$

60 Tak twierdzi F.W. Gingrich, „The Greek New Testament as a Landmark in the Course of Semantic Change", JBL 73 (1954) 189-196 (w szczególności 194).

$61 \quad$ Np. Wj 25,37; 27,20; 30,7.8; 40,4.25; Kpł 24,2.4; Lb 4,9; 8,2.3; 1Sm 3,3; 2Sm 21,17; 22,29; $2 \mathrm{Krl} 8,29 ; 1 \mathrm{Kr} 28,15 ; 2 \mathrm{Kr} 4,20.21 ; 13,11 ; 21,7 ; 29,7 ; 2 \mathrm{Mch} 10,3$; Prz 6,23; 31,18; Hi 18,6; 21,17; Syr 26,17; So 1,12; Za 4,2; Jer 25,10.

62 Już w Apokryficznym liście Jakuba (z II lub III w. po Chr.) pojawia się wzmianka o lampach dziewic z Mt 25,1-13; zob. Nag Hammadi Codex I, 2, p.1,1-16,30; zob. też Biblioteka z Nag Hammadi. Kodeksy I i II (red. i thum. W. Myszor) (Katowice: Księgarnia św. Jacka 2008) 41-48.

63 Pochodnie nasączone materiałem palnym nie były stosowane w starożytności (przynajmniej nie ma na to dowodów); inaczej twierdzi Jeremias (Le parabole di Gesù, 214).

64 Mayordomo, „Le ragazze sagge arrivano ovunque...”, 779.

${ }_{65} \sigma \beta \varepsilon ́ v v v v \tau \alpha 1$-ind. praes. act. W znaczeniu iteratywnym podkreślałby wiele prób, jakie podejmują dziewczęta, by rozpalić pochodnie. Mayordomo, „Le ragazze sagge arrivano ovunque...”, 780. 
25,8b), oznacza to, że zapomniały napełnić ów zbiorniczek ( $\dot{\alpha} \gamma \gamma \varepsilon i ̃ o v)$ oliwą ${ }^{66}$. Jednak próby rozpalenia pochodni miałyby sens, gdyby orszak weselny wyruszył zaraz po przybyciu oblubieńca. Tak się nie dzieje. Oblubieniec wchodzi do domu. Poza tym, czy rzeczywiście panny czekałyby na oblubieńca ze zgaszonymi pochodniami?

\subsubsection{Wnioski}

W przypadku pochodni brak oliwy podkreślałby roztargnienie dziewcząt (w ogóle nie wzięły oliwy), w przypadku lamp uwypuklałby błędną kalkulację (nie wzięły zapasowej oliwy). W przypadku lamp okazałyby się nieprzewidujące i nieodpowiednio przygotowane. W przypadku pochodni roztrzepane i bezmyślne, a groteskowość sytuacji dodatkowo uwydatniałaby ich gapiostwo. Tak więc, zła kalkulacja (lampy) czy zwykłe gapiostwo (pochodnie)? Wydaje się, że opóźnienie się

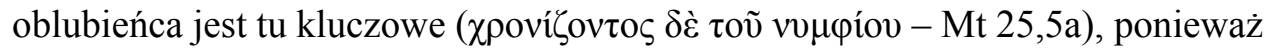
nie tylko sprawiło, że dziewczęta posnęły, ale również oliwa w lampach wypaliła się. W przypadku pochodni od samego początku pozbawionych oliwy, pora przybycia pana młodego nie miałaby żadnego znaczenia ${ }^{67}$. Pochodnie nie zapaliłyby się tak czy inaczej.

Owszem użycie pochodni ( $\lambda \alpha \mu \pi \alpha ́ \delta \varepsilon \varsigma)$ w otwartej przestrzeni mogłoby mieć wymiar symboliczny i przypominać słowa Jezusa z Kazania na Górze: „Tak niech wasze światło jaśnieje ( $\lambda \alpha \mu \psi \alpha ́ \tau \omega)$ przed ludźmi, aby widzieli wasze dobre uczynki i chwalili Ojca waszego, który jest w niebie” (Mt 5,16). Z kolei wejście na ucztę z Oblubieńcem symbolizowałoby nagrodę życia wiecznego (zob. też Mt $25,21.23$ ). Płonące pochodnie w otwartej - publicznej przestrzeni (dobre uczyn$\mathrm{ki}^{68}$ ) i wejście na ucztę weselną byłyby dwoma etapami chrześcijańskiego życia. Przy takiej alegorycznej interpretacji, pochodnie nie muszą być wniesione do domu ani oświetlać orszak. Wystarczy, że płoną.

Inną kwestią jest, dlaczego pan młody kazał na siebie czekać aż do północy

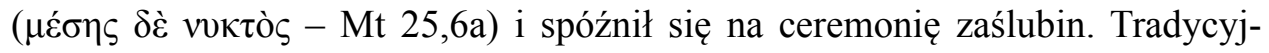
ne wyjaśnienie, choć nie do końca udokumentowane, głosi, że stało się tak, bo pertraktacje, na jaką kwotę pieniędzy ma opiewać kontrakt małżeński, trwały do późna $\mathrm{w}$ nocy ${ }^{69}$.

66 P.-B. Smit, Food and Fellowship in the Kingdom. Studies in the Eschatological Meal and Scenes of Utopian Nutritional Abundance in the New Testament (WUNT II/234; Tybinga; Mohr Siebeck 2008) 246.

67 Nolland, The Gospel of Matthew, 1006.

68 Olej jako symbol dobrych uczynków, zob. K.P. Donfried, „The Allegory of the Ten Virgins (Matt. 25:1-13) as a Summary of Matthean Theology”, JBL 93 (1974) 415-428.

69 Jeremias, Le parabole di Gesù, 212. 


\subsubsection{Los panien nieroztropnych - newralgiczny punkt opowieści}

Komentatorzy są niekiedy zaskoczeni końcową sceną, bo jak to możliwe, by podczas wesela w małej żydowskiej wiosce goście byli potraktowani w tak obcesowy sposób. Dlaczego panny roztropne nie pomogły towarzyszkom? Dlaczego mała w sumie nieuwaga kosztowała tak dużo? Dlaczego drzwi się zatrzaskują, a słowa pana młodego brzmią jak wyrok śmierci? Ma się wrażenie, że Jezus celowo wywołał te pytania, by skłonić słuchaczy do refleksji nad zawartym tu przesłaniem. Przedstawiając dobrze znany obyczaj w krzywym zwierciadle uwypuklił to, co należało dostrzec i wziąć sobie do serca.

Newralgicznym momentem przypowieści jest więc końcowa scena. Osadzona w Sitz im Leben ukazuje zarówno los pięciu nierozgarniętych panien, które ponoszą karę nieproporcjonalną do popełnionego „przewinienia”, jak i znienawidzone oblicze społeczeństwa, gdzie ocenia się ludzi na podstawie ich umiejętności dostosowania się do przyjętych schematów, często niesprawiedliwych. Bez Sitz im Leben - bez owego tła kulturowo-społecznego - hiperbola literacka byłaby dla dzisiejszego czytelnika nieuchwytna, bo nie znając żydowskich zwyczajów nie wiedziałby, jak bardzo zachowanie pana młodego wykraczało poza schemat normalnego zachowania. W ten sposób przypowieść może prowadzić do dwóch różnych reakcji: albo wzbudza w słuchaczach krytyczne pytania, czy to oni nie są przypadkiem współodpowiedzialni za zaistniałą sytuację pełną niesprawiedliwości, albo skłania ku interpretacji alegorycznej, wyprowadzając swe przesłanie poza Sitz im Leben. W tym drugim przypadku zło społeczne nie powinno być poddane ocenie wartościującej zgodnie z kanonami etycznego postępowania (podobnie jak nieuczciwość rządcy, którego Pan pochwalił w Łk 16,1-8), lecz stać się metaforą innego zła, które wykracza poza ziemską doczesność i społeczne uwarunkowania.

\subsubsection{Konkluzja}

Jeśli środowisko patriarchalne jest właściwym Sitz im Leben przypowieści, to ani na jej podstawie ani na podstawie dostępnych źródeł nie potrafimy zrekonstruować zwyczajów weselnych, do których nawiązuje Jezus. Trudno jest ustalić bowiem, gdzie panny czekają, co trzymają w ręku, czy do którego momentu ceremonii zaślubin nawiązuje przedstawiona scena. Nie znamy powodów, dla których panny oczekują oblubieńca, ani dlaczego oblubieniec spóźnił się. Niektóre elementy pasują do ogólnej wiedzy, jaką czerpiemy z Miszny i innych źródeł starożytnych (niekoniecznie żydowskich). I to one pozwalają postawić parę hipotez wokół detali, które stoją u podstaw różnych interpretacji. 
Jednak Jezus uwypuklił trzy elementy, które są ważne dla Jego przesłania teologicznego: współzawodnictwo, spóźnienie się pana młodego, los pięciu panien nierozsądnych. Ponieważ znajdują wspólny mianownik w osobie i zachowaniu oblubieńca, rodzi się pytanie o jego tożsamość. To prowadzi egzegezę do kolejnego problemu - do chrystologii.

\subsection{Problem z Amen (czy oblubieńcem jest Jezus?)}

Pan młody rozpoczyna swą wypowiedź uroczystym Amen (zaprawdę): ,Zaprawdę (⿳亠丷厂甲v) powiadam wam, nie znam was" (Mt 25,12). Wprowadzające amen jest typową cechą uroczystych wypowiedzi Jezusa w ewangeliach ${ }^{70} \mathrm{i}$ w pismach apokryficznych (np. w Ewangelii Piotra 10,371). Egzegeza wykazała bowiem, że amen miało $\mathrm{z}$ reguły sens responsoryjny, potwierdzający wcześniejsze pytanie bądź wypowiedź ${ }^{72}$. Tylko nieliczne przykłady wskazują ${ }^{73}$, że amen mogło wprowadzać indywidualną wypowiedź Boga (Testament Abrahama 8,7), uosobionej śmierci (Testament Abrahama, 20,2a) bądź człowieka składającego przysięgę (Targum Neofiti do Lb 5,2274). Z kolei Talmud babiloński mówi, że amen oznacza przysięgę (jak w Lb 5,22), przyjęcie wezwania (jak w Pwt 27,26) lub potwierdzenie wypowiedzi (jak w Jer 28,6) ${ }^{75}$.

Na tym tle wypowiedź oblubieńca skłania wielu komentatorów, by utożsamić go z Jezusem i potwierdzić tradycyjną egzegezę: tu nie mówiłby zwykły człowiek, ale Syn Człowieczy - eschatologiczny sędzia, który wydaje wyrok potępienia i sankcjonuje śmierć pięciu nierozgarniętych panien ${ }^{76}$. Ich śmierć społeczna sym-

$70 \quad$ Np. Mt 5,18.26; 6,2.16; 8,10; 10,15.23.42; 11,11; 13,17; 16,28; 17,20; 18,3.13.18.19; 19,23.28; $21,21.31 ; 23,36 ; 24,2 ;$ Mk 11,23; 14,28; Łk 18,17; 18,29 i wiele innych.

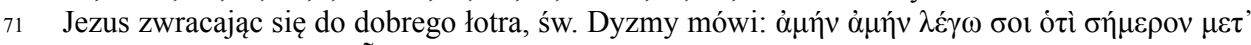

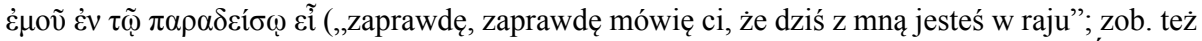
Łk 23,43) (M.G. Mara, Il vangelo di Pietro (Bologna: EDB 2003) 54-58; tenże (red.), Évangile de Pierre: Introduction, Texte Critique, Traduction, Commentaire et Index [Sources Chrétiennes 201; Paris: Les Éditions du Cerf 1973] 83-85).

72 J. Jeremias, „Zum nichtresponsorischen Amen”, Zeitschrift für die neutestamentliche Wissenschaft 64 (1973) 122-123; V. Hasler, Amen: Redaktionsgeschichtliche Untersuchung zur Einführungsformel der Herrenworte ,Wahrlich ich sage euch “ (Zurych - Stuttgart: Gotthelf Verlag 1969); K. Berger, „Zur Geschichte der Einleitungsformen «Amen, ich sage euch»”, Zeitschrift für die neutesamentliche Wissenschaft 63 (1972) 45-75; J. Strugnell, ,'Amen, I Say Unto You' in the Sayings of Jesus and in Early Christian Literature", The Harvard Theological Review 67/2 (1974) 177-182.

73 Strugnell, ,'Amen, I Say Unto You'”, 177-182.

74 Kobieta oskarżona o cudzołóstwo w Lb 5,19-22 zostaje poddana próbie, podczas której ma przysiąc według Targumu: na pewno (amen) nie stałam się nieczysta i na pewno (amen) nie stanę się nieczysta".

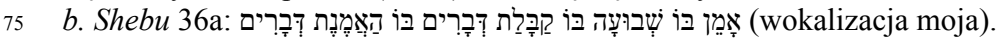

76 Schottroff, Le parabole di Gesù, 50 (przypis 7). 
bolizowałaby śmierć wieczną. Jednak wewnętrzna dynamika przypowieści i kontekst kulturowo-teologiczny wydaje się przeczyć takiej identyfikacji. Po pierwsze, obraz uczty weselnej w tradycji biblijnej nie kojarzył się z Sądem Ostatecznym, lecz z radością i zbawieniem ${ }^{77}$. I choć nadejście mesjasza niosło z sobą ukaranie bezbożników, to jednak biblijne obrazy Sądu Ostatecznego są jednoznaczne i nie potrzebują tak zawoalowanej alegoryzacji, stępiającej ostrość przestrogi i utrudniającej jej zrozumienie (w Mt 25,31-46 wiadomo, kto jest sędzią, kto będzie zbawiony, kto potępiony, i dlaczego). Po drugie, Sąd Ostateczny nie daje możliwości naprawienia popełnionych wcześniej błędów, natomiast panny nieroztropne starają się zaradzić swej niefrasobliwości, idą do sprzedających oliwę i ponawiają próbę wejścia do domu weselnego. Dostrzegły swój błąd i go naprawiły, a mimo to spotykają się z odmową. Postawa pana młodego nie odpowiada więc chrystologii, jaka znamy z ewangelii. Jezus wobec skruchy grzesznika zawsze okazuje miłosierdzie. Jeśli wypowiedź oblubieńca przypomina formalnie styl Jezusa, jej treść nie jest wypełniona ewangeliczną chrystologią ${ }^{78}$.

Tego typu spostrzeżenia prowadzą jednych egzegetów do uwypuklenia warstwy redakcyjnej, która nałożyła się na pierwotną wersję przypowieści (stąd niezgodności między formą i treścią wypowiedzi oblubieńca). Inni z kolei idą w kierunku interpretacji dosłownej i widzą w oblubieńcu uosobienie niesprawiedliwości społecznej. W tym drugim przypadku oblubieńcem nie byłby Jezus, a opisane wydarzenie byłoby zwyczajową sytuacją, która nie wykluczała pewnych szokujących zachowań (tu: obcesowe zachowanie pana młodego), ale jednak możliwych. Słuchacze przypowieści skonfrontowani z taką sytuacją muszą uświadomić sobie, że zło społeczne, które dzieje się na ich oczach, oczekuje reakcji.

\subsection{Pozostałe problemy i próba ich rozwiązania}

Poza problemami egzegetycznymi, wymienionymi w poprzednich paragrafach (§§ 2.1.- 2.3.), warto wskazać inne, które potwierdzałyby istnienie warstwy redakcyjnej, będącej próbą dostosowania przypowieści do opóźniającej się paruzji. Niewykluczone też, że wspólnota Mateuszowa, dostrzegając trudności z właściwym zrozumieniem tego obrazu, wyniosła go na poziom alegorii. A zatem sam tekst kanoniczny sugerowałby alegoryczną interpretację, którą tradycyjna egzegeza wiernie rozwinęła.

77 Innym problemem jest utożsamienie mesjasza $\mathrm{z}$ oblubieńcem, co sugeruje Jeremias i Gnilka (Jeremias, Le parabole di Gesù, 61; J. Gnilka, „«Bräutigam»-spätjüdisches Messiaspraedikat?”, Trierer Theologische Zeitschrift 69 (1960) 298-301). Jednak tu sprawa jest bardziej dyskusyjna niż uważają ci dwaj autorzy (zob. np. Iz 61,10).

78 Gnilka, „«Bräutigam»-spätjüdisches Messiaspraedikat?”, 298-301. 
Na obróbkę redakcyjną mogą wskazywać trzy elementy. Po pierwsze, umiejscowienie przypowieści między dwiema innymi przypowieściami mówiącymi o paruzji Syna Człowieczego (Mt 24,45-51 i Mt 25,14-30) ${ }^{79}$. Końcowy werset przypowieści („Czuwajcie więc, bo nie znacie dnia ani godziny” - Mt 25,13) wpisywałby przypowieść w kontekst paruzji, stając się wprowadzeniem do następnej przypowieści. Jeśli zaśnięcie dziewcząt w w. 5 jest niewinne (warstwa oryginalna), czuwanie w w. 13 jest kwestią życia lub śmierci (warstw redakcyjna $)^{80}$. Dlatego w. 13 uważany jest za redakcyjny dodatek.

Po drugie, podział na panny mądre i głupie (w. 2) antycypuje zakończenie przypowieści ${ }^{81}$, które ten podział uzasadnia ${ }^{82}$. Jednak na końcu przypowieści nie

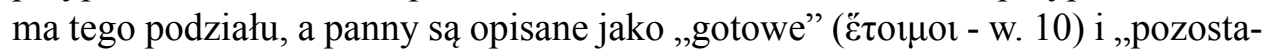

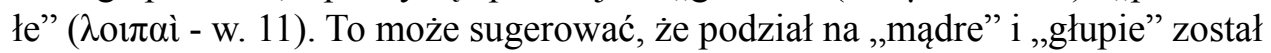
dodany na etapie redakcji Mateuszowej ${ }^{83}$.

Po trzecie, podwójne wezwanie „Panie, Panie” w w. 11 pasuje bardziej do kontekstu Sądu Ostatecznego i opisuje błaganie człowieka skierowane do uwielbionego Chrystusa. Poza tym przywodzi na myśl Mt 7,22-23 (,Wielu powie Mi w owym dniu: Panie, Panie, czy nie prorokowaliśmy ... i nie czyniliśmy wielu cudów mocą Twego imienia? Wtedy oświadczę im: Nigdy was nie znałem..."). Dlatego niektórzy egzegeci wykazują ${ }^{84}$, że Mt 7,22 czerpie inspirację z przypowieści o dziesięciu pannach, zinterpretowanej przez wspólnotę Mateuszową w kluczu paruzji.

Na podstawie tych spostrzeżeń wysuwa się hipotezę o redakcyjnym pochodzeniu kanonicznej przypowieści Mt 25,1-13, dając jednocześnie asumpt do hipotetycznej rekonstrukcji jej oryginalnej wersji.

79 Redakcyjny charakter może mieć również przysłówek czasowy „wtedy”, wprowadzający przypowieść (Mt 25,1).

80 Nolland, The Gospel of Matthew, 1006.

81 E. Güttgemanns, „Narrative Analysis of Synoptic Texts”, Semeia 6 (1976) 144: „The narrator gives to each of five virgins an anticipatory Marking that must correspond in the later development of the narrative to an Identification ... In this way, the marking initially appears as the judgment of the omniscient narrator..., then in the "narrative mode" when the mōrai-protagonists are identified as unprepared helpers ... and the phronimoi-protagonists as prepared helpers...".

82 Przeciwstawienie $\mu \omega \rho$ ó (głupi) - $\varphi \rho o ́ v ı \mu$ (roztropny) znajduje się jedynie w zakończeniu Kazania na Górze (Mt 7,24-27), co wskazuje na jego funkcję dydaktyczną, którą wspólnota mogła wykorzystać w przypowieści o dziesięciu pannach.

83 H. Weder, Metafore del regno (Brescia: Paideia 1991) 284.

84 Weder, Metafore del regno, 284; E. Schweizer, Das Evangelium nach Matthäus (NDT 2; Göttingen: Vandenhoeck\&Ruprecht 1973) 304. 


\section{Hipotetyczna rekonstrukcja pierwotnej warstwy przypowieści i problem autorstwa}

\begin{tabular}{|c|c|}
\hline Tekst grecki & Tekst polski \\
\hline 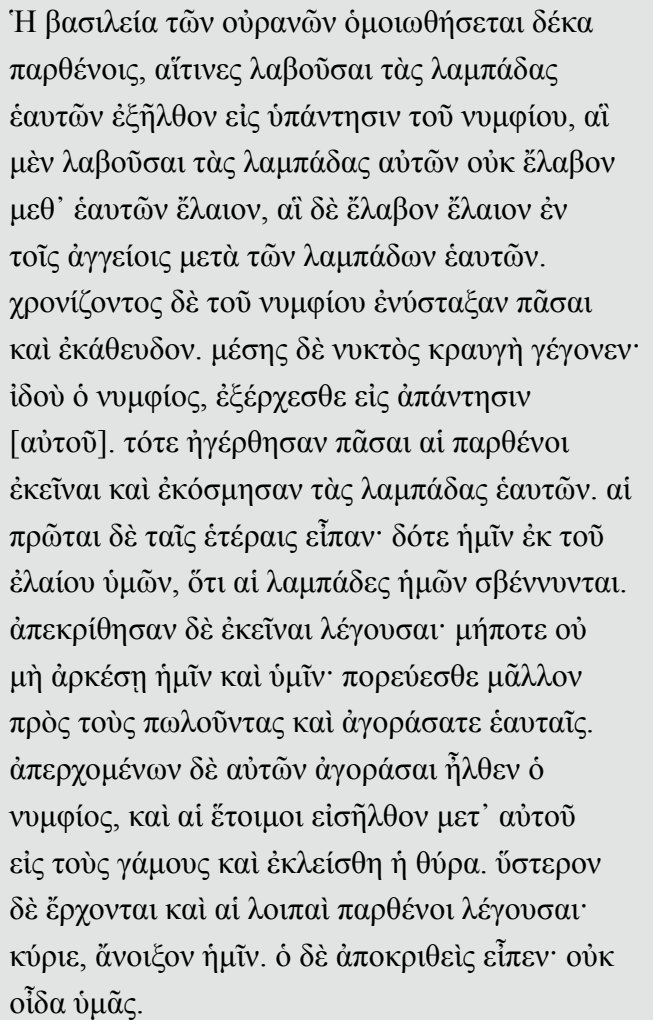 & $\begin{array}{l}\text { Królestwo niebieskie będzie podobne } \\
\text { do dziesięciu panien, które wzięły } \\
\text { swoje lampy i wyszły na spotkanie pana } \\
\text { młodego. Jedne wzięły lampy, ale nie } \\
\text { wzięły z sobą oliwy. Pozostałe zaś razem } \\
\text { z lampami zabrały również oliwę w swoich } \\
\text { naczyniach. Gdy się pan młody opóźniał, } \\
\text { senność ogarnęła wszystkie i posnęły. } \\
\text { Lecz o północy rozległo się wołanie: } \\
\text { Oto pan młody [idzie], wyjdźcie mu na } \\
\text { spotkanie! Wtedy powstały wszystkie } \\
\text { owe panny i opatrzyły swe lampy. A jedne } \\
\text { panny rzekły do drugich: Użyczcie nam } \\
\text { swej oliwy, bo nasze lampy gasną. Te zaś } \\
\text { odpowiedziały: Mogłoby i nam, i wam nie } \\
\text { wystarczyć. Idźcie raczej do sprzedających } \\
\text { i kupcie sobie. Gdy tamte szły kupić, } \\
\text { nadszedł pan młody. Te, które były gotowe, } \\
\text { weszły z nim na ucztę weselną, i drzwi } \\
\text { zamknięto. Nadchodzą w końcu i pozostałe } \\
\text { panny, prosząc: Panie, otwórz nam! Lecz } \\
\text { on odpowiedział: Nie znam was. }\end{array}$ \\
\hline
\end{tabular}

Przedstawiona rekonstrukcja stawia pytanie o autorstwo przypowieści, ponieważ proces prowadzący do powstania jej kanonicznej formy był prawdopodobnie złożony i zdeterminowany przynajmniej dwoma czynnikami ${ }^{85}$ : $\mathrm{z}$ jednej strony wersją pierwotną pochodzącą od Jezusa, $z$ drugiej zaś, wersją redakcyjną. Niektóre elementy wskazują na Jezusa, inne z kolei na Mateusza i jego wspólnotę. Temat królestwa Bożego, będący cechą charakterystyczną przepowiadania Jezusa (zob. Mk 1,15) oraz gatunek literacki przypowieści - ulubiona forma Jego nauczania ${ }^{86}$,

85 Istnieje też hipoteza o trzech etapach powstania przypowieści: 1 etap-ustne przepowiadanie Jezusa (wersja oryginalna przypowieści); 2 etap - redakcja pochodząca od wspólnoty przedmateuszowej; 3 etap - redakcja Mateuszowa (kanoniczna); zob. Weder, Metafore del regno, 285.

86 M. Lehmann, Synoptische Quellenanalyse und die Frage nach dem historischen Jesu (Berlin: de Gruyter 1970) 391 
zakorzenia przypowieść w przedpaschalnej działalności Mistrza z Nazaretu i odnosi bezpośrednio do Niego. Jednak w okresie popaschalnym, kiedy powstaje kanoniczna forma Ewangelii, wspólnota Mateusza bądź sam Ewangelista dokonał akomodacji teologicznej przypowieści wobec wyzwań, przed jakimi wspólnota stanęła w drugiej połowie I w. Takimi wyzwaniami mogło być opóźnienie się paruzji ${ }^{87}$ lub pojawienie się we wspólnocie fanatyzmu apokaliptycznego, który koncentrował się na ustaleniu daty powtórnego przyjścia Jezusa. Warto jednak zauważyć, że wersja redakcyjna nie wyeliminowała rażących nieścisłości i różnic z wersją oryginalną, co doprowadziło z jednej strony do powstania szeregu trudności z jej interpretacją, z drugiej zaś do otwarcia nowych perspektyw interpretacyjnych.

\section{Tradycyjna (metaforyczna) interpretacja przypowieści}

Postać oblubieńca i postawa panien, oczekujących na jego przybycie, znajdują się centrum każdej z trzech scen, które tworzą przypowieść. W pierwszej scenie oblubieniec jest tym, na którego się czeka; w drugiej jest tym, który ma przybyć; w trzeciej tym, który już przybył. Pięć dziewcząt popełnia błąd, który staje się jasny w drugiej scenie, a konsekwencje są ukazane w trzeciej: nie zostają wpuszczone do domu weselnego ${ }^{88}$. Na czym polegał ich błąd? Z powierzchownej lektury wynikałoby, że nie wzięły zapasu oleju, by podtrzymać płomień w lampach. To niedopatrzenie byłoby nie tyle wynikiem lekceważenia, ile błędnego mniemania, że oblubieniec przyjdzie w momencie, które same określiły (a przecież nikt nie wiedział, kiedy to nastąpi $)^{89}$. Innymi słowy pomyliły się w swoich rachubach. Stają się więc uosobieniem błędnego przekonania, że to one będą w centrum uwagi i nadadzą uroczystości weselnej splendor i rozgłos. Przypowieść uczy, że tym, który stoi w centrum jest oblubieniec i od niego zależy moment przybycia na ucztę i rozpoczęcie wesela. Gotowość nie polega na ustalaniu chwili jego przybycia ${ }^{90}$, lecz na otwartości umysłu, by przyjąć go bezwarunkowo i bezinteresownie. Dlatego napiętnowanie pięciu nieroztropnych panien jest krytyką tych, którzy uważają, iż mogą wyliczyć moment paruzji191.

87 Jeremias, Le parabole di Gesù, 61: „Gli accenni alla parusia non hanno... posto alcuno nel tessuto originario della parabola“.

88 Analiza retoryczna, ukazująca dynamikę trzech obrazów, zob.: E. Güttgemanns, „Narrative Analysis of Synoptic Texts”, Semeia 6 (1976) 144-152; zob. też analiza literacka A. Puig i Tàrrech, La parabole des dix vierges (Mt 25, 1-13) (AnBib 102; Rome: PIB 1984).

89 Nolland, The Gospel of Matthew, 1006.

90 Samo pojęcie „gotowości” jest niewystarczające do zrozumienia przypowieści. Nieco inaczej uważa D.A. Hagner (Matthew 14-28 [WBC 33B; Nashville, TN: Nelson 1995] 727).

91 Niewykluczone, że mamy tu do czynienia z krytyką apostazji bądź hipokryzji niektórych członków wspólnoty Mateuszowej. E. Schweizer, The Good News according to Matthew (London: SPCK 1976) 302-303: „The four parables of the weeds, the unforgiving servant, the 
Jeśli oblubieńcem w Starym Testamencie i w judaizmie międzytestamentalnym był Bóg92 a uczta weselna była obrazem eschatologicznego wypełnienia, przypowieść ukazuje przybycie Boga, które determinuje postawy i zachowania oczekujących ludzi. Dlatego tak ważna w przypowieści jest odpowiedź, jakiej człowiek udziela przychodzącemu Bogu. Polega ona na podtrzymywaniu w sobie ciągłej świadomości, że Bóg przybywa, choć nie ma ustalonego momentu Jego przybycia.

Jednak przypowieść wydaje się dotykać również dynamiki królestwa Bożego (Mt 25,1), bo Bóg przychodzi ze swym królestwem, czyli z władzą, którą pragnie roztoczyć nad ludzkimi sercami i umysłami. Sam Jezus w przedpaschalnym przepowiadaniu ukazywał królestwo Boże jako rzeczywistość dynamiczną, która w swej istocie jest bliska. Jej bliskość nie dotyczyła jednak porządku chronologicznego tak, by mogła być wyrażona w kategoriach czasu, lecz była bliskością relacyjną, mającą bezpośredni związek z najbliższym otoczeniem i teraźniejszością (zob. też Łk 17,20-21). Z tego powodu przypowieść może być krytyką ludzkiej ciekawości, chcącej wyliczyć moment nadejścia królestwa Bożego, tak jakby było ono rzeczywistością odległą i nieuchwytną w teraźniejszości. Takie wyliczanie wynikałoby z niewłaściwego rozumienia istoty królestwa Bożego, które objawia się tu i teraz, choć - by je dostrzec i przyjąć - trzeba mieć „oczy, które widzą i uszy, które słyszą”. Problemem jest więc to, jak dostrzec ową bliskość i otworzyć się na nią.

Jeśli w nauczaniu Jezusa królestwo Boże jest bezpośrednią relacją Boga z czasem obecnym, to jednak nie można mówić o całkowitym utożsamieniu królestwa Bożego z teraźniejszością, tak jakby oba porządki nakładały się na siebie (w przeciwnym razie zatarłyby się różnice między Bogiem i światem). Z drugiej zaś strony nie można królestwa Bożego zrelatywizować czy , unieważnić” jako rzeczywistości odległej w czasie. Odpowiednim opisem dynamiki królestwa Bożego będzie wpisanie jej w teologiczne napięcie ,już-jeszcze” (iam-nondum). Rodzi się jednak pytanie, czy owa dynamika w przypowieści jest bardziej ,już” czy raczej „jeszcze nie”. Wydaje się, że mówi się tu raczej o królestwie Bożym jako rzeczywistości, która nadchodzi w teraźniejszości, niż o jego pełnym objawieniu w czasie paruzji. Zinterpretowana w takim kluczu, przypowieść uczy właściwego podejścia do otaczającego i teraźniejszego świata. Ustanawiając związek między przybyciem Boga i naszą teraźniejszością, nie pozwala czło-

wedding garment, and the virgins... deal with the apostasy of sameone in the comunity"; zob. też F. Thielman, Theology of the New Tesament. A Canonical and Synthetic Approach (Grand Rapids, MI: Zondervan 2005) 107; R.H. Gundry, „In Defense of the Church in Matthew as a Corpus Mixtum", Zeitschrift für neutestamentliche Wissenschaft und die Kunde der älteren Kirche 91 (2000) 153-165; rzeczywiście pojęcie „hipokryzji” pojawia się w Mt 24,51 bezpośrednio przed Mt 25,1.

92 Hagner (Matthew 14-28, 727) widzi w oblubieńcu motyw mesjański. 
wiekowi na ucieczkę ze świata w jakiś fanatyzm apokaliptyczny, który stanowi zagrożenie dla chrześcijańskiej wiary.

Aby dostrzec królestwo Boże w teraźniejszości i otworzyć się na nie należy rozpoznać przychodzącego Boga w Jego Synu - Jezusie. Nieprzypadkowo w Nowym Testamencie On też jest nazwany oblubieńcem (2Kor 11,2; Ef 5,2532; Ap 19,7-9; 21,2.99 ${ }^{93}$. W Jego osobie Bóg wkracza w czasoprzestrzeń człowie-

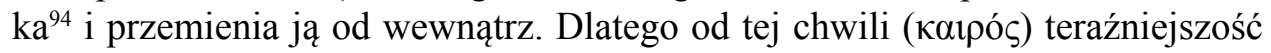
staje się miejscem i czasem podjęcia decyzji w obliczu Boga, który przybywa. Gotowość do podjęcia decyzji jest kluczowa, bo od niej zależy, czy dostrzeżemy nadejście Boga, czy też pozostanie ono dla nas niezauważone. W Jezusie nadszedł czas, by otworzyć serce na takie wyczekiwanie, w którym nie ma miejsca na ludzką rachubę czy kalkulację. Postawa powodowana wyrachowaniem czy kalkulacją nie pozwaliłaby bowiem na uczestnictwo w mesjańskiej uczcie - nie pozwaliłaby wejść do królestwa Bożego tu i teraz. Być uczestnikiem zbawienia oznacza przyjąć postawę umożliwiającą spotkanie z Bogiem, który przybywa w swym Synu i w Nim objawia swoją wolę.

Przypowieść jest też przestrogą przed sądem, jaki czeka tych, którzy nie potrafią wejść w perspektywę wiary i są powodowani jedynie ludzką kalkulacją. Ta przestroga ma wymiar paruzyjno-eschatologiczny, bo przyszłość nigdy nie jest oderwana od teraźniejszości, lecz tę teraźniejszość determinuje i określa ${ }^{95}$. Całość przesłania przybiera więc formę ewangelicznej parenezy, jak i gdzie osiągnąć zbawienie.

\section{Interpretacja alternatywna (kontekstualna) ${ }^{96}$ przypowieści}

W interpretacji kontekstualnej przypowieść Mt 25,1-13 jest historią o złym traktowaniu osób, które na to nie zasłużyły, co więcej krzywda spotyka je w kontekście święta i wesela. Jeżeli weźmiemy pod uwagę uwarunkowania kulturowe, można powiedzieć, że na nierozgarniętych pannach dokonuje się swoistego rodzaju lincz społeczny. Zostają im zatrzaśnięte drzwi do szczęśliwego życia

93 Luz, A Commentary on Matthew 21-28, 232.

94 J. Lambrecht, „The Wise and Foolish Virgins (Matthew 25:1-13)”, In Once More Astonished: The Parables of Jesus (New York: Crossroad 1981) 146-166; Hagner, Matthew 14-28, 728.

95 Opóźnianie się paruzji mogło być wezwaniem do większej otwartości na drugiego człowieka i na wyzwania, przed którymi stawała wspólnota Mateuszowa. Ewangelista za pomocą redakcyjnych wstawek mógł uwypuklić nieprzewidziany charakter przybycia Syna Człowieczego.

96 Interpretacja kontekstualna polega na zrozumieniu tekstu w określonych warunkach kulturowohistorycznych. Akty działania człowieka, jego myślenie i czucie mogą bowiem prowadzić do różnych konsekwencji, jeśli uwarunkowania kulturowe są różne. Jezus wzywając do nawrócenia (zmiany mentalności, gr. $\mu \varepsilon \tau$ óvol $\alpha$ ) musiał brać pod uwagę ów kulturowy kontekst, który wpływał na mentalność odbiorców i utrudniał im zrozumienie logiki Boga. 
małżeńskiego, bo zostały publicznie napiętnowane i ośmieszone jako osoby nieporadne (zob. wyżej $\S \S ~ 2.1 .1$ i 2.1.2). Wypowiedź pana młodego („nie znam was") jest usankcjonowaniem tej sytuacji. Przypowieść opisuje więc rozpaczliwą sytuację pięciu kobiet, które nie okazały się na tyle bystre, by zadbać o swoją przyszłość małżeńską, i zostają ukarane niewspółmiernie do popełnionego błędu. Ukazuje sytuację osób, które odstają od przyjętych odgórnie ludzkich schematów i są za to „karane” wykluczeniem społecznym.

\subsection{Przypowieść $w$ kontekście mowy eschatologicznej Jezusa (Mt 24-25)}

W poszukiwaniu znaczenia przypowieści należy zadać sobie pytanie: gdzie tu jest ewangelia? Wypowiedź pana młodego „nie znam was” niesie w sobie sporą dawkę okrucieństwa, które podświadomie wywołuje sprzeciw i oburzenie. Nawet ci, którzy nadają tym słowom sens metaforyczny, mają kłopot $\mathrm{z}$ tonem wypowiedzi, tym bardziej że kobiety nierozsądne starały się jednak zaradzić sytuacji i naprawić swe niedbalstwo.

Metoda historyczno-krytyczna, szukająca rozwiązania problemu, zakorzenia przypowieść w mowie eschatologicznej (Mt 24-25) - najbliższym kontekście, do którego przypowieść należy. Z tym literackim kontekstem łączą ją dwa elementy: motyw czuwania ( $\gamma \rho \eta \gamma о \rho \varepsilon i ̃ \tau \varepsilon-M t ~ 25,13)$ i przysłówek czasowy „wtedy” ( - Mt 25,1). Motyw czuwania pojawia się w mowie eschatologicznej Jezusa dwa razy (Mt 24,42.44; zob. też Mt 24,36.50) i współgra logicznie z nieoczekiwanym przybyciem oblubieńca o północy (Mt 25,6). Z drugiej jednak strony, zachęta do czuwania (Mt 25,13) nie znajduje pozytywnego przykładu do naśladowania, bo wszystkie panny, również te roztropne posnęły ${ }^{97}$, a zatem żadna z nich nie wypełniła tego wezwania. Poza tym Jezus nie wyrzuca im, że posnęły, lecz to że pięć $\mathrm{z}$ nich nie miało zapasu oliwy. Samo czuwanie nie jest $\mathrm{w}$ centrum zainteresowania. Jeśli więc - mimo to - ewangelista dodaje taką zachętę do oryginalnej przypowieści w w. 13 (zob. wyżej § 4), pragnie osadzić ją głębiej w mowie eschatologicznej i wzmocnić przesłanie o potrzebie czuwania.

Drugim elementem łączącym przypowieść z kontekstem literackim jest przysłówek czasowy „wtedy” ( $\tau$ ó $\varepsilon-\mathrm{Mt} 25,1)$. Pojawia się w mowie eschatologicznej 17 razy (Mt 24,9.10.14.16.21.23.30.34.40; 25,1.7.31.34.37.41.44.45), z których 4 użycia związane są z logiką narracji (Mt 25,7.34.37.41), pozostałe $13 \mathrm{ma}$ wydźwięk eschatologizujący. Częstotliwość użycia tego przysłówka sugeruje,

97 Zwraca na to uwagę Jeremias (Le parabole di Gesì, 61): „...questa esortazione finale alla vigilanza [v. 13] non coglie il senso della parabola. Tutte infatti dormono, le vergini savie come le stolte (v. 5)". 
że jest on ważny dla właściwego zrozumienia przypowieści, bo jeśli na samym początku pojawia się ,wtedy” (Mt 25,1), samoistnie narzuca się pytanie: kiedy? Odpowiedź na to pytanie wymaga szerszego spojrzenia na mowę eschatologiczną w Mt 24-25. Warto bowiem zauważyć, że jest ona odpowiedzią na pytanie uczniów, skierowane do Jezusa: „Powiedz nam, kiedy to nastąpi i jaki będzie znak Twego przyjścia ( $\pi \alpha \rho o v \sigma i ́ \alpha)$ i końca świata ( $\alpha i \omega ́ v)$ ?” (Mt 24,8). W tym pytaniu są zarysowane dwa czasy: czas zniszczenia świątyni i czas przyjścia Jezusa jako Syna Człowieczego na Sąd Ostateczny. Również Jezus - w odpowiedzi, jakiej udziela uczniom - dokonuje podziału czasu eschatologicznego na dwa

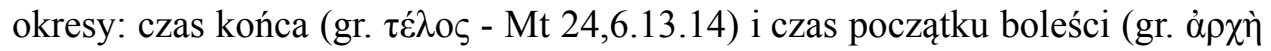
ஸ́dív $\omega v$ - Mt 24,8). Końcem jest królestwo Boże, kiedy „Bóg będzie wszystkim we wszystkich" (1Kor 15,28). Zniszczenie zaś świątyni wpisuje się w ciąg wydarzeń, które wyznaczają początek boleści poprzedzających koniec. Tymi wydarzeniami są: pojawienie się fałszywych mesjaszy, proroków i innych samozwańczych głosicieli zbawienia (Mt 24,5.11.24-28), wojny (Mt 24,6.7.16-21.40.41), okresy głodu i trzęsienia ziemi (Mt 24,7), polityczne prześladowanie uczniów Jezusa - którym zapowiada, że będą wydawani na śmierć (Mt 25,9) - wewnętrzny rozkład wspólnoty wierzących z powodu oziębłości w miłości, nieprzestrzeganie prawa i zdrady (Mt 24,10.12).

Skoro przysłówek ,wtedy” może odnosić się do dwóch okresów eschatologicznych, również przypowieść, wprowadzona przez ten przysłówek, może odnosić się albo do czasu końca (jak Mt 25,31-46) albo do czasu początku boleści. Interpretacja kontekstualna wybiera jednak tę drugą opcję ${ }^{98} \mathrm{i}$ widzi w przypowieści jeden z obrazów ilustrujących początek boleści.

\subsection{Przesłanie przypowieści w interpretacji kontekstualnej}

Przypowieść opowiada o groźnym obliczu teraźniejszości, w której obok wojen, głodu, fałszywych mesjaszy, zdrady i braku miłości obecna jest niesprawiedliwość społeczna. Obraz w swym przesłaniu staje się mocniejszy, jeśli połączymy go z obrazem pokolenia Noego (Mt 24,37-41). Oba obrazy przedstawiają postępowanie ludzkości w przeddzień nadejścia królestwa Bożego. Z jednej strony, teraźniejszość jest zinterpretowana za pomocą biblijnej historii: ludzkość nie chce się nawrócić, jak wtedy, gdy za dni Noego groziła jej zagłada. Dalej niewzruszenie prowadzi codzienne życie, jedząc i pijąc, wychodząc za mąż, żeniąc się, tak jakby ten świat ze swymi zwyczajami miał trwać wiecznie. Z drugiej strony, przypowieść Mt 25,1-13 dodaje do tego obrazu niesprawiedliwość społeczną, która zakłóca normalny tok życia. 
Werset wprowadzający („Wtedy królestwo niebieskie będzie podobne do dziesięciu panien, które wzięły swoje lampy i wyszły na spotkanie pana młodego") ustanawia więc pewną symetrię między teraźniejszością a królestwem niebieskim. Obok obrazu teraźniejszości naznaczonej niesprawiedliwością, mamy drugi, odniesiony do królestwa niebieskiego. Oba obrazy zestawione ze sobą wymagają zrozumienia, by wejść na drogę nawrócenia. Jeśli słuchacze mają spojrzenie wiary (zob. Mt 13,13-17), dostrzegą w teraźniejszości działanie nadchodzącego Boga, który położy kres wszelkiej niesprawiedliwości. Przypowieść ze swymi skrótami myślowymi, pełnymi niedomówień, uczy, że obecny świat, w którym panuje niesprawiedliwość i współzawodnictwo, stanie się niebawem miejscem sprawiedliwości i Bożego panowania. W samym opowiadaniu nie ma najmniejszego znaku nadziei - nawet zakończenie przypowieści brzmi złowieszczo: „nie znam was”. Podobnie było za dni Noego. Jednak Jezus w Mt 24,39 mówi swym uczniom, że właśnie pośród zła i niegodziwości, objawi się Syn Człowieczy ze swą zbawczą mocą (Mt 24,39). Niesprawiedliwość, jej wzmożenie i wszechobecność stają się znakiem nadchodzącego końca i bliskości królestwa Bożego (ale nie w sensie czasowym, linearnym, lecz relacyjnym - zob. wyżej § 4).

Trzy przypowieści z mowy eschatologicznej (Mt 24,45-51; 25,1-13.14-30) umiejscawiają doświadczenie teraźniejszości, pełnej zła i niegodziwości w kontekście działania Boga Zbawcy. Ukazują, że tam, gdzie króluje teraz zło, zapanuje królestwo niebieskie. Tam, gdzie zło ukazuje swe najgroźniejsze oblicze, tam właśnie nadchodzi Syn Człowieczy ze swoją mocą. Przez cierpienie i zło czasu obecnego zaczyna przezierać królestwo Boże i Boża sprawiedliwość. W tak zinterpretowanej przypowieści wybrzmiewa Dobra Nowina - ewangelia.

\subsection{Problem z ó}

Problemem w interpretacji kontekstualnej jest jednak czasownik ó $\mu \circ \omega \theta \eta ́ \sigma \varepsilon \tau \alpha \imath$ (ind. fut. pass. od ó $\mu$ otoṽv), otwierający przypowieść i tłumaczony zwyczajowo „będzie podobne” (Mt 25,1). W takim thumaczeniu królestwo Boże jako rzeczywistość pozytywna „upodabnia się” do rzeczywistości negatywnej, którą jest niesprawiedliwość i wykluczenie społeczne. Dwa elementy stojące do siebie w sprzeczności nie mogą być do siebie podobne. Jednak problem z formułami

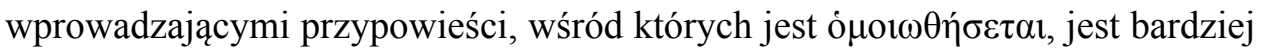
złożony, niż mogłoby się wydawać przy pierwszej lekturze ${ }^{99}$.

99 Bardzo często język grecki LXX i Nowego Testamentu może być właściwie zrozumiany jedynie przez pryzmat frazeologii, gramatyki i syntaksy hebrajskiej. Wydaje się, że tu mamy do czynienia z takim przypadkiem. 
Grecka formuła wprowadzająca przypowieść ${ }^{100}$ jest kalką językową przeniesioną z języka hebrajskiego (ewentualnie aramejskiego), gdzie tytuł przypowie-

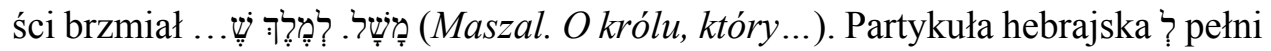
często funkcję datiwu, dlatego tak jest thumaczona na język grecki. Wprowadze-

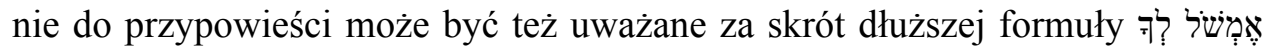
(Chce opowiedzieć ci przypowieść. Do czego porównam sprawę? Porównam ja do...). Dlatego grecka formuła wprowadzająca przypo-

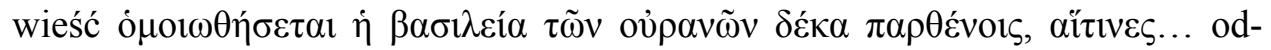

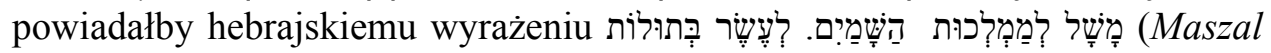
o królestwie niebieskim. O dziesięciu pannach, które.... $)^{101}$. Punktem odniesienia nie są panny, lecz królestwo Boże i zachęta, by słuchacz maszalu miał na tyle otwarte oczy i uszy, by dostrzec, gdzie kryje się rzeczywistość królestwa Bożego. Tak jak nasze życie nieustannie konfrontujemy z wartościami królestwa Bożego (np. robiąc rachunek sumienia), tak Jezus zachęca nas, byśmy skonfrontowali obraz przedstawiony w przypowieści - zaczerpnięty z życia codziennego - z wartościami królestwa Bożego. To zestawienie byłoby istotą czasownika hebrajskiego Dlatego formę ó $\mu$ ot $\omega \theta \dot{\sigma} \sigma \varepsilon \tau \alpha \iota$ należałoby raczej przetłumaczyć „będzie skonfrontowane”, „skonfrontuje się", ,zostanie zestawione”, „zostanie porównane”. Takie zestawienie może być pozytywne, będące u podłoża podobieństwa. Ale

100 Mateusz używa osiem razy czasownika ó $\mu$ otoṽv (Mt 6,8; 7,24.26; 11,16;13,24; 18,23;22,2; 25,1) na 15 wszystkich użyć w Nowym Ttestamencie (Mk 4,30; Łk 7,31; 13,18.20; Dz 14,11; Rz 9,29; Hbr 2,17). Warto też zauważyć, że pośród czterech przypowieści: o chwastach, bezlitosnym słudze, stroju weselnym i dziesięciu pannach, trzy pierwsze zaczynają się aorystem passivi

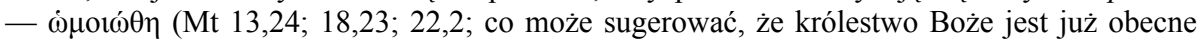
w teraźniejszości: zob. M. Stallard, „Hermeneutics and Matthew 13. Part II”, Conservative Theological Journal 16/5 [2001] 345; M.L. Bailey, „The Parable of the Tares”, Bibliotheca Sacra 155 [1998] 266-279), natomiast czwarta zaczyna się od futurum passivi - ó $\mu$ ot $\theta \dot{\theta} \sigma \varepsilon \tau \alpha 1$ (Mt 25,1; co może otwierać perspektywę należącą do przyszłości). W odróżnieniu od Łukasza, gdzie podobna konstrukcja pojawia się w stronie czynnej (Łk 13,18-19.20-21), ónotoṽ $v$ w stronie biernej ma u Mateusza charakter semityzujący - bardziej przypomina hebrajskie wprowadzenia do maszalów.

101 P. Fiebig, Rabbinische Gleichnisse (Leipzig: Hinrichs 1929) 3-4.9-10.14.17.21-23; Jeremias, Le parabole di Gesù, 123-125: „Questo $\mathrm{l}^{\mathrm{e}}$ è un'abbreviazione ... e non può essere tradotto con «è simile a...», ma deve essere tradotto «la cosa sta nei riguardi di.... come con...»... Il Regno di Dio... non è «simile a un mercante», ma simile a una perla; ... non è «simile a dieci vergini», ma ad una festa di nozze; ... non è «simile a un re», ma ad un banchetto nuziale; ... non è «simile a un padrone di casa», ma al versamento del salario..."; Schottroff, Le parabole di Gesù, 166: „Molti racconti parabolici raffigurano delle strutture sociali che sono in contraddizione con la volontà e l'agire di Dio, con il suo regno. Io le chiamo parabole antitetiche. Intendere il «paragone» (ómotoṽv) come invito a metterli formalmente sullo stesso piano... rappresenta un fraintendimento"; zob. też J. Trela, Przypowieści Jezusa a meszalim (Lublin: Wydawnictwo KUL 1997) 54-56; Trela koncentruje uwagę na przypowieściach zaczynających się od pytań.

102 Koehler - Baumgartner - Stamm, Wielki stownik hebrajsko-polski i aramejsko-polski Starego Testamentu, I, 214; J. Lust - E. Eynikel - K. Hauspie, Greek-English Lexicon of the Septuagint (Stuttgart: Deutsche Bibelgesellschaft 2003) 437. 
może być to też zestawienie negatywne, gdzie nie ma żadnego podobieństwa. Interpretacja kontekstualna przypowieści o dziesięciu pannach uwypukla negatywny obraz niesprawiedliwości wobec królestwa Bożego nadchodzącego z mocą już w teraźniejszości.

Przypowieść nie wykazuje podobieństwa królestwa Bożego do jakiegoś złego wydarzenia, lecz opowiada zwyczajne ludzkie życie w czasie, kiedy Bóg przychodzi, by zainaugurować swe panowanie na ziemi. Jego nadejście jest czystą łaską przynoszącą zbawienie - wydarzeniem, które ukazuje ludzkości jej nędzę duchową i moralną, i jednocześnie wzbudza w sercu człowieka nadzieję na rychłe objawienie się Bożego zbawienia. Słuchacze przypowieści są wezwani, by zestawili

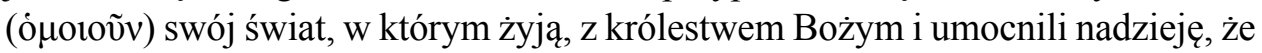
Bóg odnowi upadły świat z grzechu i zła. Ci, którzy są w stanie tego dokonać, zaczynają rozpoznawać w cierpiących i wykluczonych Jezusa - Syna Człowieczego nadchodzącego w swej chwale, by osądzić świat (zob. Mt 25,31-46).

Owo zestawienie jest możliwe wtedy, gdy wejdzie się na drogę nawrócenia. Nie jest to więc ćwiczenie intelektualne czy bystrość umysłu, ale otwarcie się na łaskę Boga, który daje nowe oczy zdolne zobaczyć, i nowe uszy - zdolne usłyszeć. W przeciwnym razie jest to niemożliwe. Dlatego zatrzaśnięte drzwi w Mt 25,10 to symbol świata, który zmierza do końca, ale również znak bliskości królestwa Bożego. Wspólnota uczniów Jezusa wychodzi mu naprzeciw.

\subsection{Jakiej odpowiedzi oczekuje Jezus od słuchaczy przypowieści?}

Przypowieści oczekują odpowiedzi ze strony słuchaczy, dlatego Mateusz dodaje na koniec wezwanie: „czuwajcie...” ( $\gamma \rho \eta \gamma о \rho \varepsilon i \tau \varepsilon-M t ~ 25,13)$. Skoro ostatnia scena ukazuje, że drzwi się zamykają i dziewczęta, które nie wytrzymały presji współzawodnictwa, zostają wykluczone, uczniowie Jezusa powinni zareagować. Skoro oblubieniec (uosobienie zła społecznego) was nie zna, my uczniowie Jezusa, zaczyn królestwa Bożego na ziemi, znamy was i przyjmujemy. Drzwi naszego serca nigdy się przed wami nie zamkną. Mamy jeszcze czas, zanim nadejdzie Sędzia (Mt 25,31-46), by położyć kres niesprawiedliwości i przemocy ${ }^{103}$.

Pamięć o Sądzie Ostatecznym w przeżywaniu doczesności jako czasu boleści jest mobilizująca i skłania do działania na rzecz królestwa Bożego na ziemi w oczekiwaniu na jego pełne objawienie w chwale niebieskiej. Dlatego interpretacja kontekstualna łączy obraz zamkniętych drzwi (jako symbolu niesprawiedliwości społecznej) z obrazem zamkniętych drzwi (jako symbolu wiecznego potępienia), który mógł być inspiracją do przedstawienia Sądu Ostatecznego w Ap 3,7-8: „To mówi Święty, Prawdomówny, Ten, co ma klucz Dawida, Ten,

103 Schottroff, Le parabole di Gesù, 59. 
co otwiera, a nikt nie zamknie i Ten, co zamyka, a nikt nie otwiera. Znam twoje czyny. Oto postawiłem jako dar przed tobą drzwi otwarte, których nikt nie może zamknąć, bo ty, chociaż moc masz znikomą, zachowałeś moje słowo i nie zaparłeś się mojego imienia". Wspólnota Kościoła, podobnie jak ta z Filadelfii, do której św. Jan pisze szósty list w Apokalipsie, musi więc pamiętać, że możliwość, iż Bóg zamknie drzwi przy Sądzie Ostatecznym jest częścią ewangelii i nie wolno jej lekceważyć. Przypowieść zinterpretowana w takim kluczu nie rozstrzyga, kto będzie zbawiony, kto potępiony, lecz ukazując rodzajową scenkę z życia żydowskiej wioski, w której dzieje się niesprawiedliwość, skłania do refleksji nad własnym postępowaniem i zachęca do działania w zgodzie z wartościami królestwa Bożego, ukazanymi w Kazaniu na Górze (Mt 5-7).

\section{Zakończenie}

Jeśli oblubieńcem w metaforycznej interpretacji jest sam Jezus - Syn Człowieczy, eschatologiczny Sędzia, w interpretacji kontekstualnej jest on uosobieniem zła społecznego, wobec którego uczeń Jezusa musi zareagować. Obie interpretacje znajdują punkt zbieżności w przesłaniu, by żyć wartościami królestwa Bożego hic et nunc, w ziemskiej doczesności, pamiętając o Sądzie Ostatecznym. Jeśli interpretacja metaforyczna kładzie akcent na groźbie potępienia wiecznego i wywiera presję, by skłonić czytelnika do działania, interpretacja kontekstualna osiąga ten cel inaczej: pozytywnie uwrażliwia czytelnika na zło społeczne, by otworzyć jego oczy i uszy, i pomóc mu dostrzec cierpiących i potrzebujących, w których cierpi Jezus.

Podobnie motyw zatrzaśniętych drzwi może być interpretowany na dwa sposoby - jako obraz nieodwołalności Bożego wyroku (interpretacja metaforyczna) lub jako obraz wykluczenia społecznego (interpretacja kontekstualna). Jednak i tutaj oba obrazy znajdują punkt zbieżności w wezwaniu czytelnika, by nie tracił żadnej okazji na poszukiwanie woli Bożej, bo taka okazja może już więcej się nie nadarzyć. W takim rozumieniu pomaga żydowski maszal rabina Haniny bar-Hamy (III w. po Chr.), ucznia Judy ha-Nasiego, w którym motyw zamkniętych drzwi ma właśnie takie znaczenie:

„Pewna karawana szła drogą po pustyni. Gdy zaczął zapadać zmrok, przechodziła obok karawanseraju. Naczelnik karawanseraju zawołał do nich: «Wejdźcie do środka i uchrońcie się od dzikich zwierząt i złoczyńców». Ale naczelnik karawany odmówił: «Nie mam zwyczaju wchodzić do karawanseraju!». I poszedł dalej. Ale gdy nadeszła noc, zmienił zdanie i zawrócił do karawanseraju. Zawezwał naczelnika i poprosił go, by mu otworzył. Wtedy naczelnik karawanseraju odrzekł: «Nie otwiera się w nocy karawanseraju, a ja nie mam zwyczaju 
przyjmować nikogo o tak późnej porze! Kiedy cię zapraszałem, nie chciałeś, a teraz ja nie mogę ci otworzyć»»" Tak mówił Święty Izraela: «Wróćcie, synowie wiarołomni» (Jr 3,14). A potem: «Szukajcie Pana, gdy się pozwala znaleźć» (Iz 55,6). A skoro żaden z nich nie wraca, Święty powiedział: «Pójdę i wrócę do mojej siedziby» (Oz 5,15). Kiedy zostali przekazani bogatym tego świata i poganom, krzyknęli: «Dlaczego stoisz z dala, o Panie?» (Ps 10,1; 22,1). A On im odpowiedział: «Kiedy was zapraszałem, nie przyjęliście zaproszenia; to teraz, kiedy Mnie szukacie, Ja was nie słyszę». Jak Kuba Bogu, tak Bóg Kubie. Jest bowiem napisane „Ponieważ oni nie słuchali, kiedy wołałem, i Ja nie wysłucham, kiedy oni wołać będą” (Za 7,13)”"104.

Choć motyw zamkniętych drzwi jest podobny, to jednak widać różnice między przypowieściami Jezusa i żydowskimi maszalami. Te pierwsze wzywają czytelnika bezpośrednio do nawrócenia, mówią o grzechu, miłości i miłosierdziu, te drugie zaś służą raczej do interpretacji Pisma Świętego i podejmując kwestie jurystyczno-hermeneutyczne, starają się wyjaśnić sytuację Żydów w określonym kontekście historycznym ${ }^{105}$.

\section{Bibliografia}

Aguirre Monasterio, R. - Rodríguez Carmona, A., Vangeli Sinottici e Atti degli Apostoli (Brescia: Paideia 1995).

Bailey, M.L., „The Parable of the Tares”, Bibliotheca Sacra 155 (1998) 266-279.

Balabinski, V., „Opening the Closed Door: A Feminist Rereading of «Wise and Foolish Virgins» (Mt 25,1-13)", The Lost Coin. Parables of Women, Work and Wisdom (red. M.A. Beavis) (London New York: Sheffield Academic Press 2002) 71-97.

Berger, K., „Zur Geschichte der Einleitungsformen «Amen, ich sage euch»”, Zeitschrift für die neutesamentliche Wissenschaft 63 (1972) 45-75.

Biblioteka z Nag Hammadi. Kodeksy I i II (red. i thum. W. Myszor) (Katowice: Księgarnia św. Jacka 2008).

Cyceron, In Catilinam oratio tertia (red. C. Stegmann, Die Rede über den Oberbefehl des Cn. Pompeius und die Katilinarischen Reden [Leipzig - Berlin: Teubner 1912] 55-67).

Cyceron, In Catilinam oratio quarta (red. C. Stegmann, Die Rede über den Oberbefehl des Cn. Pompeius und die Katilinarischen Reden [Leipzig - Berlin: Teubner 1912] 68-79).

Cyceron, De legibus (red. i thum. C.W. Keyes, Cicero on the Republic, on the Laws [Loeb Classical Library 213; Cambridge, MA: Harvard University Press 1928] 235-287).

Cyceron, De re publica (red. i thum. C.W. Keyes, Cicero on the Republic, on the Laws [Loeb Classical Library 213; Cambridge, MA: Harvard University Press 1928] 369-402).

104 D. Flusser, Die rabbinischen Gleichnisse und der Gleichniserzähler Jesus. 1 Teil. Das Wesen der Gleichnisse (Bern-Frankfurt a.M - Las Vegas: Verlag Peter Lang 1981) 25.

105 Lehmann, Synoptische Quellenanalyse, 39; zob. też F. Lambiasi, L'Autenticità storica dei Vangeli (Bologna: EDB 1978); Trela, Przypowieści Jezusa a meszalim, 226-227. 
Chadwick, H. - Oulton, J.E. (red.), Alexandrian Christianity (Library of Christian Classics; Philadelphia: Westminster 1954).

Czerski, J., „Interpretacja tekstów biblijnych w liturgii”, Studia Theologica Varsoviensia 49/1 (2011) 153-154.

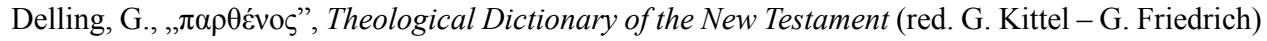
(Grand Rapids, MI: Eerdmans 1995) V, 826-837.

Didache (red. J. Harris) (Baltimore-London: Johns Hopkins University; C.J. Clay \& Son 1883).

Donfried, K.P. „The Allegory of the Ten Virgins (Matt. 25:1-13) as a Summary of Matthean Theology", Journal of Biblcal Literature 93 (1974) 415-428.

Egger, W., Metodologia del Nuovo Testamento (Bologna: Edizioni Dehoniane 1996).

Fiebig, P., Rabbinische Gleichnisse (Leipzig: Hinrichs 1929).

Filippi, A. - Lora, E. (red.), Enchiridion biblicum (Bologna: Edizioni Dehoniane $\left.{ }^{2} 1994\right)$.

Flusser, D., Die rabbinischen Gleichnisse und der Gleichniserzähler Jesus. 1 Teil. Das Wesen der Gleichnisse (Bern-Frankfurt/M - Las Vegas: Verlag Peter Lang 1981).

Gnilka, J., „«Bräutigam» - spätjüdisches Messiaspraedikat?”, Trierer Theologische Zeitschrift 69 (1960) 298-301.

Gingrich, F.W., „The Greek New Testament as a Landmark in the Course of Semantic Change”, Journal of Biblcal Literature 73 (1954) 189-196.

Granqvist, H., Marriage Conditions in a Palestinian Village (Helsinki: Societas Scientiarum Fennica 1935) I-II.

Gryglewicz, F., „Dziewictwo w greckiej terminologii biblijnej”, Roczniki Teologiczno-Kanoniczne 22/1 (1975) 25-37.

Gundry, R.H., „In Defense of the Church in Matthew as a Corpus Mixtum”, Zeitschrift für neutestamentliche Wissenschaft und die Kunde der älteren Kirche 91 (2000) 153-165.

Güttgemanns, E., „Narrative Analysis of Synoptic Texts”, Semeia 6 (1976) 144-152.

Hagner, D.A., Matthew 14-28 (WBC 33B; Nashville, TN: Nelson 1995).

Hamman, A. (red.), Patrologia Latina Supplementum (Paryż: Éditions Garnier Frères 1958-1974) III.

Hasler, V., Amen: Redaktionsgeschichtliche Untersuchung zur Einführungsformel der Herrenworte „Wahrlich ich sage euch“ (Zurych - Stuttgart: Gotthelf Verlag 1969).

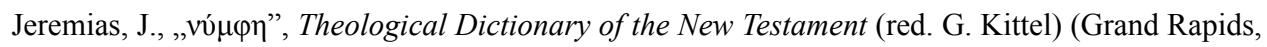
MI: Eerdamans 1967) IV, 1099-1106.

Jeremias, J., Le parabole di Gesù (Brescia: Paideia ${ }^{2} 1973$ ).

Jeremias, J., „Zum nichtresponsorischen Amen”, Zeitschrift für die neutestamentliche Wissenschaft 64 (1973) 122-123.

Jones, T.R., „Union With Christ: The Existential Nerve Of Puritan Piety”, Tyndale Bulletin 41/2 (1990) 186-209.

Klinger, F. (red.), Quinti Horatii Flacci Opera (Leipzig: Teubner $\left.{ }^{5} 1970\right)$.

Koehler, L. - Baumgartner, W. - Stamm, J.J., Wielki stownik hebrajsko-polski i aramejsko-polski Starego Testamentu (Warszawa: Vocatio 2008).

Kongregacja ds. Instytutów Życia Konsekrowanego i Stowarzyszeń Życia Apostolskiego, Ecclesiae Sponsae Imago, https://press.vatican.va/content/salastampa/it/bollettino/pubblico/2018/07/04/ 0508/01125.html\#IT [dostęp: 26.04.2019].

Lambrecht, J., „The Wise and Foolish Virgins (Matthew 25:1-13)”, In Once More Astonished: The Parables of Jesus (New York: Crossroad 1981) 146-166. 
Lambiasi, F., L'Autenticità storica dei Vangeli (Bologna: EDB 1978).

Lehmann, M., Synoptische Quellenanalyse und die Frage nach dem historischen Jesu (Berlin: de Gruyter 1970).

Lust, J. - Eynikel, E. - Hauspie, K., Greek-English Lexicon of the Septuagint (Stuttgart: Deutsche Bibelgesellschaft 2003).

Luz, U., A Commentary on Matthew 21-28 (Hermeneia 61C; Minneapolis, MN: Fortress Press 2005). Mayordomo, M., „Le ragazze sagge arrivano ovunque...”, Compendio delle parabole di Gesù (red. R. Zimmermann) (Brescia: Queriniana 2011) 771-793.

Metzger, B.M., A Textual Commentary on the Greek New Testament (Stuttgart - New York: Deutsche Bibelgesellschaft/United Bible Societies 1998).

Migne, J.-P. (red.), Patrologiae cursus completus. Series latina (Paryż: Migne 1844-1846) XXXVIII.

Motyer, J.A., Prophecy of Isaiah. An Introduction and Commentary (Downers Grove, IL: InterVarsity 1993).

Nolland, J., The Gospel of Matthew. A Commentary on the Greek Text (NIGTC; Grand Rapids, MI: Eerdmans 2005).

Oakley, J.H. - Sinos, R.H., The Wedding in Ancient Athens (Madison, WI: University of Wisconsin Press 1994).

Orygenes, Commentariorum series in evangelium Matthaei (red. E. Klostermann) (Die Griechischen christlichen Schriftsteller der ersten drei Jahrhunderte 35; Leipzig: J.C. Hinrich 1933).

Owidiusz, Tristia. Ex Ponto (red. i thum. A.L. Wheeler - G.P. Goold) (Loeb Classical Library 151; Cambridge, MA: Harvard University Press 1924).

Paciorek, A., Przypowieści Jezusa. Wprowadzenie i objaśnienie (Częstochowa: Edycja Świętego Pawła 2013).

Pagenkemper, K.E., „Rejection Imagery in the Synoptic Parables”, Bibliotheca Sacra 153/609 (1996) 308-331.

Papieska Komisja Biblijna, Interpretacja Pisma Świętego w Kościele (Poznań: Pallotinum 1994).

Parisinou, E., „Lighting the World of Women. Lamps and Torches in the Hands of Women in the Late Archaic and Classical Periods", Greece and Rome 47 (2000) 19-43.

Puig i Tàrrech, A., La parabole des dix vierges (Mt 25, 1-13) (AnBib 102; Rome: PIB 1984).

Quarles, Ch. L., Matthew. Exegetical Guide to the Greek New Testament (Nashville, TN: B\&H Publishing Group 2017).

Reuss, J. (red.), Matthäus-Kommentare aus der griechischen Kirche (Berlin: Akademie-Verlag 1957).

Ryken, L. - Wilhoit, J.C. - Longmann III, T. (red.), Le immagini bibliche. Simboli, figure retoriche e temi letterari della Bibbia (Milano: Edizioni San Paolo 2006).

Schottroff, L., Le parabole di Gesù (Brescia: Queriniana 2007).

Schweizer, E., Das Evangelium nach Matthäus (NDT 2; Göttingen: Vandenhoeck\&Ruprecht 1973).

Schweizer, E., The Good News according to Matthew (London: SPCK 1976).

Smit, P.-B., Food and Fellowship in the Kingdom. Studies in the Eschatological Meal and Scenes of Utopian Nutritional Abundance in the New Testament (WUNT II/234; Tybinga; Mohr Siebeck 2008).

Spicq, C., Theological Lexicon of the New Testament (Peabody, MA: Hendrickson 1994) III.

Stallard, M., „Hermeneutics and Matthew 13. Part II”, Conservative Theological Journal 16/5 (2001) 324-359. 
Starowieyski, M. (red.), Apokryfy Nowego Testamentu. Ewangelie Apokryficzne (Kraków: WAM 2003).

Streeter, B.H., The Four Gospels. A Study of Origins (London: Macmillian and Company 1924).

Strugnell, J., ,'Amen, I Say Unto You' in the Sayings of Jesus and in Early Christian Literature”, The Harvard Theological Review 67/2 (1974) 177-182.

Szlaga, J., „Hermeneutyka biblijna”, Wstęp ogólny do Pisma Świętego (red. J. Szlaga) (Poznań Warszawa: Pallotinum 1986).

Testaferri, F., La parola viva (Assisi: Cittadella Editrice 2009).

Thielman, F., Theology of the New Testament. A Canonical and Synthetic Approach (Grand Rapids, MI: Zondervan 2005).

Treggiari, S., Roman Marriage. Iusti Coniuges from the Time of Cicero to the Time of Ulpian (Oxford: Clarendon Paperbacks 1991).

Trela J., Przypowieści Jezusa a meszalim (Lublin: Wydawnictwo KUL 1997).

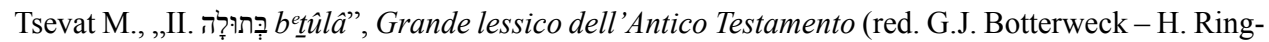
gren) (Brescia: Paideia 1988) I, 1783.

Walton, J.H. - Matthews, V.H. - Chavalas, M.W., Komentarz historyczno-kulturowy do Biblii Hebrajskiej (Warszawa: Vocatio 2005).

Weder, H., Metafore del regno (Brescia: Paideia 1991).

Wenham, G.J., „Bětûlâ: A Girl of Marriageable Age”, Vetus Testamentum 22 (1972) 325-348.

Winniczuk, L., Ludzie, zwyczaje i obyczaje starożytnej Grecji i Rzymu (Warszawa: PWN ${ }^{4} 2008$ ).

Zimmermann, R., „Das Hochzeitsritual im Jungfrauengleichnis. Sozialgeschichtliche Hintergründe zu Mt 25,1-13", New Testament Studies 48 (2002) 48-70.

Zimmermann, R. (red.), Compendio delle parabole di Gesù (Brescia: Queriniana 2011). 